\title{
Iron from Supplements Consumed During Infancy and Toddlerhood and Growth, Size, and Body Composition: A Systematic Review
}

2020 Dietary Guidelines Advisory Committee, Birth to 24 Months Subcommittee

Published date: July 15, 2020

Nutrition Evidence Systematic Review Center for Nutrition Policy and Promotion

Food and Nutrition Service

U.S. Department of Agriculture

Braddock Metro Center II 1320 Braddock Place

Alexandria, Virginia 22314 
This systematic review was conducted by the 2020 Dietary Guidelines Advisory Committee in collaboration with the Nutrition Evidence Systematic Review (NESR) team at the Center for Nutrition Policy and Promotion, Food and Nutrition Service, U.S. Department of Agriculture (USDA). All systematic reviews from the 2020 Advisory Committee Project are available on the NESR website: https://nesr.usda.gov/2020-dietary-guidelines-advisory-committeesystematic-reviews.

Conclusion statements drawn as part of this systematic review describe the state of science related to the specific question examined. Conclusion statements do not draw implications, and should not be interpreted as dietary guidance. This portfolio provides the complete documentation for this systematic review. A summary of this review is included in the 2020 Advisory Committee's Scientific Report available at www.DietaryGuidelines.gov.

The contents of this document may be used and reprinted without permission. Endorsements by NESR, the Center for Nutrition Policy and Promotion, the Food and Nutrition Service, or the USDA of derivative products developed from this work may not be stated or implied.

Suggested citation for this systematic review: 2020 Dietary Guidelines Advisory Committee and Nutrition Evidence Systematic Review Team. Iron from Supplements Consumed During Infancy and Toddlerhood and Growth, Size, and Body Composition: A Systematic Review. 2020 Dietary Guidelines Advisory Committee Project.

Alexandria, VA: U.S. Department of Agriculture, Food and Nutrition Service, Center for Nutrition Policy and Promotion, July 2020. Available at: https://nesr.usda.gov/2020-dietary-guidelines-advisory-committee-systematicreviews.

Related citation: Dietary Guidelines Advisory Committee. 2020. Scientific Report of the 2020 Dietary Guidelines Advisory Committee: Advisory Report to the Secretary of Agriculture and the Secretary of Health and Human Services. U.S. Department of Agriculture, Agricultural Research Service, Washington, DC.

In accordance with Federal civil rights law and USDA civil rights regulations and policies, the USDA, its Agencies, offices, and employees, and institutions participating in or administering USDA programs are prohibited from discriminating based on race, color, national origin, religion, sex, gender identity (including gender expression), sexual orientation, disability, age, marital status, family/parental status, income derived from a public assistance program, political beliefs, or reprisal or retaliation for prior civil rights activity, in any program or activity conducted or funded by USDA (not all bases apply to all programs). Remedies and complaint filing deadlines vary by program or incident.

Persons with disabilities who require alternative means of communication for program information (e.g., Braille, large print, audiotape, American Sign Language, etc.) should contact the responsible Agency or USDA's TARGET Center at (202) 720-2600 (voice and TTY) or contact USDA through the Federal Relay Service at (800) 877-8339. Additionally, program information may be made available in languages other than English.

To file a program discrimination complaint, complete the USDA Program Discrimination Complaint Form, AD-3027, found online at How to File a Program Discrimination Complaint and at any USDA office or write a letter addressed to USDA and provide in the letter all of the information requested in the form. To request a copy of the complaint form, call (866) 632-9992. Submit your completed form or letter to USDA by: (1) mail: U.S. Department of Agriculture, Office of the Assistant Secretary for Civil Rights, 1400 Independence Avenue, SW, Washington, D.C. 20250-9410; (2) fax: (202) 690-7442; or (3) email: program.intake@usda.gov.

USDA is an equal opportunity provider, employer, and lender. 


\section{Birth to 24 Months Subcommittee:}

- Kathryn Dewey, PhD, University of California, Davis, Subcommittee Chair

- Lydia Bazzano, MD, PhD, Tulane University and Ochsner Health System

- Teresa Davis, PhD, Baylor College of Medicine

- Sharon Donovan, $\mathrm{PhD}, \mathrm{RD}$, University of Illinois, Urbana-Champaign

- Elsie Taveras, MD, MPH, Massachusetts General Hospital, Harvard Medical School, and Harvard T.H. Chan School of Public Health

- Ronald Kleinman, MD, Massachusetts General Hospital and Harvard Medical School, Vice-Chair of the 2020 Dietary Guidelines Advisory Committee

\section{Nutrition Evidence Systematic Review (NESR) Team:}

- Darcy Güngör, MS, Analyst, Panum Group ${ }^{i}$

- Sudha Venkatramanan, PhD, Analyst, Panum Groupi

- Emily Madan, PhD, Analyst, Panum Groupi

- Laural Kelly English, PhD, MS, Analyst, Panum Groupi

- Nancy Terry, MS, MLS, Biomedical Librarian, National Institutes of Health (NIH), U.S. Department of Health and Human Services (HHS)

- Gisela Butera, MLIS, MEd, Systematic Review Librarian, Panum Group ${ }^{i}$

- Julie Obbagy, PhD, RD, Project Lead, Office of Nutrition Guidance and Analysis (ONGA), Center for Nutrition Policy and Promotion (CNPP), Food and Nutrition Service (FNS), U.S. Department of Agriculture (USDA)

\section{Federal Liaisons:}

- Cria Perrine, PhD, Division of Nutrition, Physical Activity, and Obesity, Centers for Disease Control and Prevention, HHS

- Jennifer Lerman, MPH, RD, National Cancer Institute, NIH, HHS

- Kelley Scanlon, PhD, RD, Special Nutrition Research and Analysis Division, Office of Policy Support, FNS, USDA

\section{Project Leadership:}

- Eve Essery Stoody, PhD, Designated Federal Officer and Director, ONGA, CNPP, FNS, USDA

- Janet de Jesus, MS, RD, Nutrition Advisor, Office of Disease Prevention and Health Promotion, Office of the Assistant Secretary for Health, HHS

USDA and HHS implemented a process to identify topics and scientific questions to be examined by the 2020 Dietary Guidelines Advisory Committee. The Committee conducted its review of evidence in subcommittees for discussion by the full Committee during its public meetings. The role of the Committee members involved establishing all aspects of the protocol, which presented

' Under contract with the Food and Nutrition Service, United States Department of Agriculture. 
the plan for how they would examine the scientific evidence, including the inclusion and exclusion criteria; reviewing all studies that met the criteria they set; deliberating on the body of evidence for each question; and writing and grading the conclusion statements to be included in the scientific report the 2020 Committee submitted to USDA and HHS. The NESR team with assistance from Federal Liaisons and Project Leadership, supported the Committee by facilitating, executing, and documenting the work necessary to ensure the reviews were completed in accordance with NESR methodology. More information about the 2020 Dietary Guidelines Advisory Committee, including the process used to identify topics and questions, can be found at www. DietaryGuidelines.gov. More information about NESR can be found at NESR.usda.gov.

The Committee and NESR staff thank USDA's Agricultural Research Service for coordinating the peer review of this systematic review, and the Federal scientist peer reviewers for their time and expertise.

FUNDING SOURCE: United States Department of Agriculture, Food and Nutrition Service, Center for Nutrition Policy and Promotion, Alexandria, VA 


\section{TABLE OF CONTENTS}

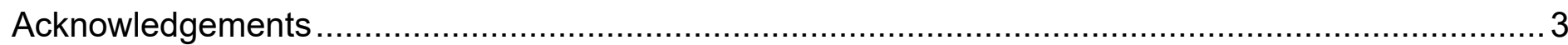

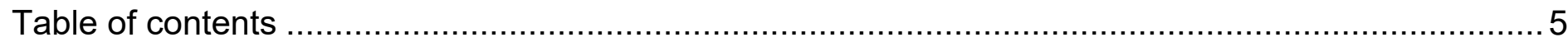

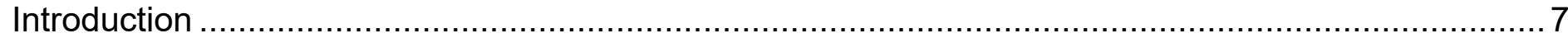

What is the relationship between iron from supplements consumed during infancy and toddlerhood

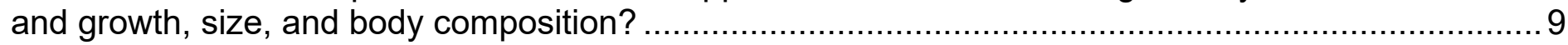

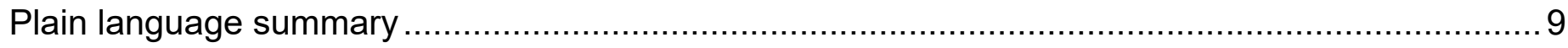

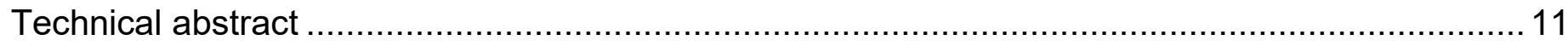

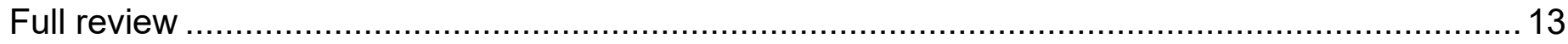

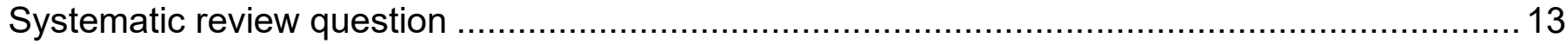

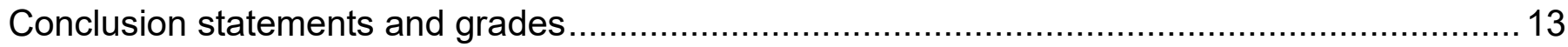

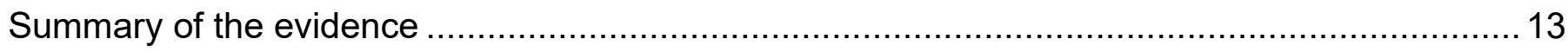

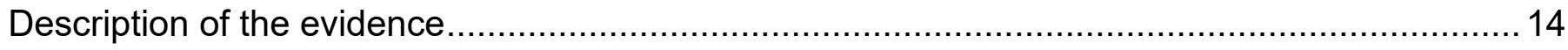

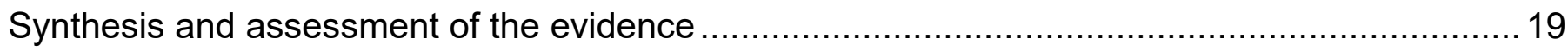

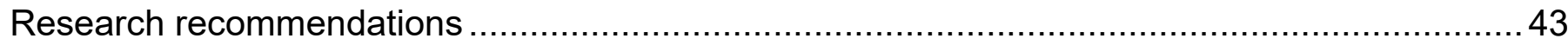

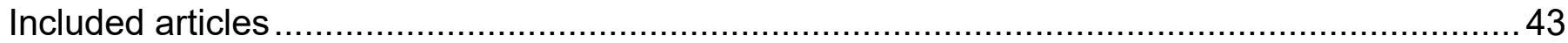

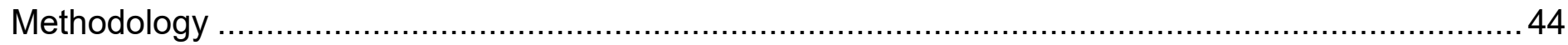

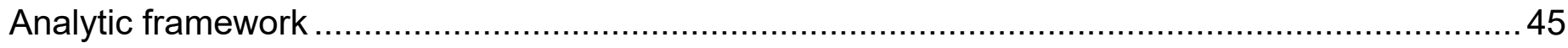

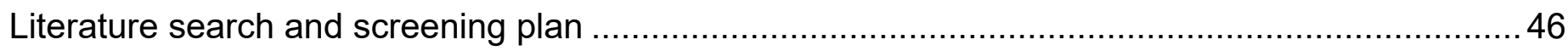

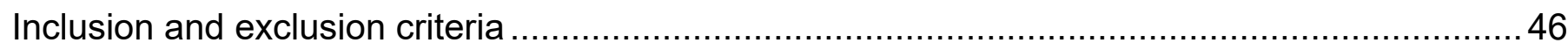

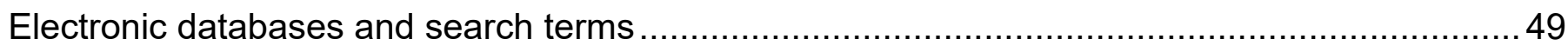

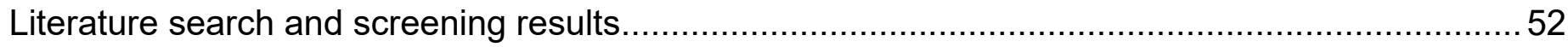

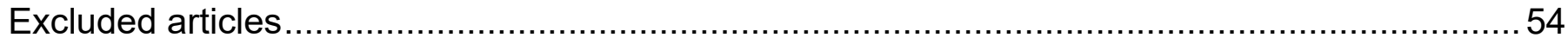

Table 1. Summary of the intervention periods, according to baseline age of infants and the duration of

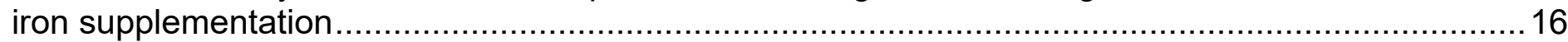

Table 2. Summary of the outcome measures, according to measures of change in size from birth or baseline to follow-up and measures of attained size at follow-up ..

Table 3. Evidence examining the relationship between iron from supplements consumed during infancy and toddlerhood and growth, size, and body composition .

Table 4. Risk of bias for randomized controlled trials examining iron from supplements consumed during infancy and toddlerhood and growth, size, and body composition

Table 5. Risk of bias for the non-randomized controlled trial examining iron from supplements consumed during infancy and toddlerhood and growth, size, and body composition.

Table 6. Risk of bias for the observational study examining iron from supplements consumed during infancy and toddlerhood and growth, size, and body composition

Table 7. Inclusion and exclusion criteria 
Table 8. Articles excluded after full text screening with rationale for exclusion

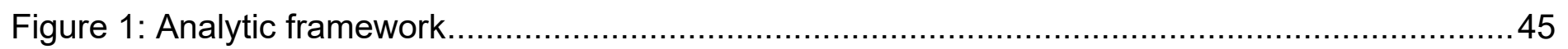

Figure 2: Flow chart of literature search and screening results ................................................53 


\section{INTRODUCTION}

This document describes a systematic review conducted to answer the following question: What is the relationship between iron from supplements consumed during infancy and toddlerhood and growth, size, and body composition? This systematic review was conducted by the 2020 Dietary Guidelines Advisory Committee, supported by USDA's Nutrition Evidence Systematic Review (NESR).

More information about the 2020 Dietary Guidelines Advisory Committee is available at the following website: www.DietaryGuidelines.gov.

NESR specializes in conducting food- and nutrition-related systematic reviews using a rigorous, protocol-driven methodology. More information about NESR is available at the following website: NESR.usda.gov.

NESR's systematic review methodology involves developing a protocol, searching for and selecting studies, extracting data from and assessing the risk of bias of each included study, synthesizing the evidence, developing conclusion statements, grading the evidence underlying the conclusion statements, and recommending future research. A detailed description of the systematic reviews conducted for the 2020 Dietary Guidelines Advisory Committee, including information about methodology, is available on the NESR website: https://nesr.usda.gov/2020-dietary-guidelinesadvisory-committee-systematic-reviews. In addition, starting on page 44, this document describes the final protocol as it was applied in the systematic review. A description of and rationale for modifications made to the protocol are described in the 2020 Dietary Guidelines Advisory Committee Report, Part D: Chapter 6. Nutrients from Dietary Supplements During Infancy and Toddlerhood. 
List of abbreviations

\begin{tabular}{ll}
\hline Abbreviation & Full name \\
\hline BMI & Body mass index \\
\hline CNPP & Center for Nutrition Policy and Promotion \\
\hline FNS & USDA Food and Nutrition Service \\
\hline HHS & U.S. Department of Health and Human Services \\
\hline NESR & Nutrition Evidence Systematic Review \\
\hline NIH & National Institutes of Health \\
\hline ONGA & Office of Nutrition Guidance and Analysis \\
\hline USDA & U.S. Department of Agriculture \\
\hline
\end{tabular}




\section{WHAT IS THE RELATIONSHIP BETWEEN IRON FROM SUPPLEMENTS CONSUMED DURING INFANCY AND TODDLERHOOD AND GROWTH, SIZE, AND BODY COMPOSITION?}

\section{PLAIN LANGUAGE SUMMARY}

\section{What is the question?}

- The question is: What is the relationship between iron from supplements consumed during infancy and toddlerhood and growth, size, and body composition?

\section{What is the answer to the question?}

- Moderate evidence indicates that human milk-fed infants who are supplemented with iron do not have greater growth, and may have slower growth, than human milk-fed infants not supplemented with iron.

- Insufficient evidence is available to determine the relationship between iron from supplements consumed during infancy and body composition during infancy.

- Insufficient evidence is available to determine the relationship between iron from supplements consumed during infancy and growth, size, and body composition beyond age 12 months.

- Insufficient evidence is available to determine the relationship between iron from supplements consumed after age 12 months and growth, size, and body composition.

\section{Why was this question asked?}

- This important public health question was identified by the U.S. Departments of Agriculture (USDA) and Health and Human Services (HHS) to be examined by the 2020 Dietary Guidelines Advisory Committee.

\section{How was this question answered?}

- The 2020 Dietary Guidelines Advisory Committee, Birth to 24 Months Subcommittee, conducted a systematic review to answer this question with support from the Nutrition Evidence Systematic Review (NESR) team.

\section{What is the population of interest?}

- Iron supplementation was examined in healthy infants and toddlers (birth to 24 months) with outcomes measured at any age.

\section{What evidence was found?}

- This review includes 10 articles.

- The articles examined infants and toddlers who consumed iron from supplements. Most studies compared infants who consumed iron from supplements with infants who did not consume iron from supplements. Fewer studies compared infants who consumed iron from supplements with infants who consumed different dosages of iron from supplements or iron from fortified foods. 
- The outcomes of interest were growth, size, and body composition at any age, however the articles only examined growth and size and almost all of the outcomes were measured during infancy.

- The evidence indicated that infants fed human milk who are supplemented with iron do not have greater growth, and may have slower growth, than infants not supplemented with iron.

- There are limitations in the evidence as follows:

- There were not a lot of articles, and some of the articles studied groups of infants and toddlers that may have been too small to detect a relationship between iron supplementation and growth or size.

- The studies differed from one another in some important ways, such as the timing of iron supplementation, infants' consumption of iron-fortified infant formula or iron-rich foods, and the study populations examined, which may have had differences in risk.

\section{How up-to-date is this systematic review?}

- This review searched for studies from January 2000 to January 2020 


\section{TECHNICAL ABSTRACT}

\section{Background}

- This important public health question was identified by the U.S. Departments of Agriculture (USDA) and Health and Human Services (HHS) to be examined by the 2020 Dietary Guidelines Advisory Committee.

- The 2020 Dietary Guidelines Advisory Committee, Birth to 24 Months Subcommittee, conducted a systematic review to answer this question with support from the Nutrition Evidence Systematic Review (NESR) team.

- The goal of this systematic review was to examine the following question: What is the relationship between iron from supplements consumed during infancy and toddlerhood and growth, size, and body composition?

\section{Conclusion statements and grades}

- Moderate evidence indicates that human milk-fed infants who are supplemented with iron do not have greater growth, and may have slower growth, than human milk-fed infants not supplemented with iron. (Grade: Moderate)

- Insufficient evidence is available to determine the relationship between iron from supplements consumed during infancy and body composition during infancy. (Grade: Grade not assignable)

- Insufficient evidence is available to determine the relationship between iron from supplements consumed during infancy and growth, size, and body composition beyond age 12 months. (Grade: Grade not assignable)

- Insufficient evidence is available to determine the relationship between iron from supplements consumed after age 12 months and growth, size, and body composition. (Grade: Grade not assignable)

\section{Methods}

- A literature search was conducted using 4 databases (PubMed, Embase, CINAHL, and Cochrane) to identify articles that evaluated the intervention or exposure of iron from supplements consumed during infancy and toddlerhood and growth, size, and body composition outcomes. A manual search was conducted to identify articles that may not have been included in the electronic databases searched. Articles were screened by two NESR analysts independently for inclusion based on pre-determined criteria.

- Data extraction and risk of bias assessment were conducted for each included study, and both were checked for accuracy. The Committee qualitatively synthesized the body of evidence to inform development of conclusion statements, and graded the strength of evidence using preestablished criteria for risk of bias, consistency, directness, precision, and generalizability.

\section{Summary of the evidence}

- Ten articles met the inclusion criteria for this systematic review, which presented evidence from 8 randomized controlled trials, 1 non-randomized controlled trial, and 1 study that did not clearly describe its prospective study design.

- The intervention or exposure of interest was iron from supplements consumed during infancy 
and toddlerhood. Dietary supplements are products that contain one or more dietary ingredients (in this case, iron) intended to be taken by mouth to supplement the diet. Nine studies examined iron supplementation during infancy, and only 1 study examined iron supplementation during toddlerhood.

- The comparators of interest were different dosages of iron from supplements and iron from fortified foods.

- The outcomes of interest were measures of growth, size, and body composition at any age. However, no articles were identified that examined outcomes beyond 24 months. The articles presented evidence about growth (i.e., change in size between birth or baseline and follow-up) and size (i.e., attained size at follow-up). However, no articles presented evidence about body composition (e.g., percent fat mass, skinfold thickness).

- Moderate evidence, from 5 studies that compared iron from supplements with no iron from supplements, indicated that human milk-fed infants who are supplemented with iron do not have greater growth, and may have slower growth, than human milk-fed infants not supplemented with iron. Inconsistencies in the evidence may be explained by differences in the risk of iron deficiency between the populations studied, differences in participants' consumption of iron-fortified formula or iron-rich foods, and differences in the timing of iron supplementation. This heterogeneity, the small number of studies, and the small sample sizes, were the primary factors limiting the ability to draw stronger conclusions.

- Evidence available from 3 studies was insufficient to determine whether a relationship exists between iron from supplements, compared with a different dosage or duration of iron from supplements, and growth or size, because the studies used heterogeneous interventions that could not be compared.

- Evidence available from 2 studies was insufficient to determine whether a relationship exists between iron from supplements, compared with iron from fortified foods, and growth or size, because the studies used heterogeneous interventions that could not be compared. 


\section{FULL REVIEW}

\section{Systematic review question}

What is the relationship between iron from supplements consumed during infancy and toddlerhood and growth, size, and body composition?

\section{Conclusion statements and grades}

Moderate evidence indicates that human milk-fed infants who are supplemented with iron do not have greater growth, and may have slower growth, than human milk-fed infants not supplemented with iron. (Grade: Moderate)

Insufficient evidence is available to determine the relationship between iron from supplements consumed during infancy and body composition during infancy. (Grade: Grade not assignable)

Insufficient evidence is available to determine the relationship between iron from supplements consumed during infancy and growth, size, and body composition beyond age 12 months. (Grade: Grade not assignable)

Insufficient evidence is available to determine the relationship between iron from supplements consumed after age 12 months and growth, size, and body composition. (Grade: Grade not assignable)

\section{Summary of the evidence}

- Ten articles met the inclusion criteria for this systematic review, ${ }^{1-10}$ which presented evidence from 8 randomized controlled trials, 1 non-randomized controlled trial, and 1 study that did not clearly describe its prospective study design.

- The intervention or exposure of interest was iron from supplements consumed during infancy and toddlerhood. Dietary supplements are products that contain one or more dietary ingredients (in this case, iron) intended to be taken by mouth to supplement the diet.i Nine studies examined iron supplementation during infancy, and only 1 study examined iron supplementation during toddlerhood.

- The comparators of interest were different dosages of iron from supplements and iron from fortified foods.

- The outcomes of interest were measures of growth, size, and body composition at any age. However, no articles were identified that examined outcomes beyond 24 months. The articles presented evidence about growth (i.e., change in size between birth or baseline and follow-up) and size (i.e., attained size at follow-up). However, no articles presented evidence about body composition (e.g., percent fat mass, skinfold thickness).

- Moderate evidence, from 5 studies that compared iron from supplements with no iron from supplements, indicated that human milk-fed infants who are supplemented with iron do not have greater growth, and may have slower growth, than human milk-fed infants not supplemented with iron. Inconsistencies in the evidence may be explained by differences

\footnotetext{
ii National Institutes of Health Office of Dietary Supplements. Dietary Supplement Health and Education Act of 1994 Public Law 103-417 103rd Congress: Sec. 3. Definitions. https://ods.od.nih.gov/About/DSHEA Wording.aspx\#sec3 Published October 25, 1994. Accessed May 18, 2020
} 
in the risk of iron deficiency between the populations studied, differences in participants' consumption of iron-fortified formula or iron-rich foods, and differences in the timing of iron supplementation. This heterogeneity, the small number of studies, and the small sample sizes, were the primary factors limiting the ability to draw stronger conclusions.

- Evidence available from 3 studies was insufficient to determine whether a relationship exists between iron from supplements, compared with a different dosage or duration of iron from supplements, and growth or size, because the studies used heterogeneous interventions that could not be compared.

- Evidence available from 2 studies was insufficient to determine whether a relationship exists between iron from supplements, compared with iron from fortified foods, and growth or size, because the studies used heterogeneous interventions that could not be compared.

\section{Description of the evidence}

This systematic review examines available evidence about the relationship between iron from supplements consumed during infancy and toddlerhood and growth, size, and body composition throughout the lifespan.

Ten articles, published between 2002 and 2016, met the inclusion criteria, including 8 randomized controlled trials, ${ }^{3-10} 1$ non-randomized controlled trial, ${ }^{1}$ and 1 study that did not clearly describe its prospective study design ${ }^{2}$ (Table 3 ).

\section{Population}

Nine studies examined infant participants, and most of these studies focused on infants fed human milk. One study examined toddlers. ${ }^{1}$ Study participants were from the United States (U.S.), ${ }^{9,10}$ Brazil, ${ }^{1,3}$ Canada, ${ }^{5}$ China, ${ }^{7}$ Italy, ${ }^{2}$ Sweden, ${ }^{4,8}$ and Turkey. ${ }^{6}$ The U.S. samples were predominantly or entirely White, and no other studies reported race or ethnicity.

Eligibility criteria related to anemia and/or iron status

Seven studies applied eligibility criteria related to anemia and/or iron status at enrollment:

- Hemoglobin $\geq 90 \mathrm{~g} / \mathrm{L},{ }^{4}$ and $\geq 110 \mathrm{~g} / \mathrm{L}^{1,3}$

- Cord blood serum ferritin $\geq 35 \mu \mathrm{g} / \mathrm{L}^{7}$

- Hemoglobin $\geq 100 \mathrm{~g} / \mathrm{L}$ and serum ferritin $\geq 12 \mu \mathrm{g} / \mathrm{L}^{8}$

- No iron deficiency ${ }^{9}$ or iron-deficiency anemia ${ }^{6}$

Three studies did not report eligibility criteria related to anemia or iron status. ${ }^{2,5,10}$

Baseline iron status

Eight studies reported mean hemoglobin at baseline:

- Azeredo et $\mathrm{al}^{1} \mathrm{1}: 124 \mathrm{~g} / \mathrm{L}$ at 6-18 months

- da Silva et $\mathrm{al}^{3}: 118-122 \mathrm{~g} / \mathrm{L}$ at 5-7 months, depending on the group

- Dewey et $\mathrm{al}^{4}: 117-121 \mathrm{~g} / \mathrm{L}$ at 4 months, depending on the group

- Friel et $\mathrm{al}^{5}: 124-126 \mathrm{~g} / \mathrm{L}$ at 1 month, depending on the group

- Hacihamdioglu et al ${ }^{6}: 112-116 \mathrm{~g} / \mathrm{L}$ at 4 months, depending on the group; this study also 
reported other iron status indicators at baseline: hematocrit 32.2-35.3\%, mean corpuscular volume 77.9-80.9 fL, mean corpuscular hemoglobin concentration 32.7-33.2 g/dL, red cell distribution width 12.2-13.1\%, ferritin 82.2-83.5 $\mu \mathrm{g} / \mathrm{L}$

- Szymlek-Gay et al ${ }^{8}: 108-113 \mathrm{~g} / \mathrm{L}$ at 6 months, depending on the group

- Ziegler et al9: 114-115 g/L at 4 months, depending on the group; this study also reported other iron status indicators at baseline: ferritin 89-134 $\mu \mathrm{g} / \mathrm{L}$, transferrin receptor 6.27-6.37 $\mathrm{mg} / \mathrm{L}$, red cell distribution width 12.3-12.4\%, mean corpuscular volume 81-82 fL

- Ziegler et $\mathrm{al}^{10}{ }^{10}: 127-132 \mathrm{~g} / \mathrm{L}$ at 1 month, depending on the group; this study also reported other iron status indicators at baseline: plasma ferritin 123-152 $\mu \mathrm{g} / \mathrm{L}$, serum transferrin receptor 5.65-5.74 mg/L, red cell distribution width $12.2-12.6 \%$, mean corpuscular volume 81-82 fL

Two studies did not report iron status at baseline. ${ }^{2,7}$ However, Lozoff et al ${ }^{7}$ reported iron status at birth (6 weeks prior to baseline):

- Lozoff et $\mathrm{al}^{7}$ : hemoglobin $149-154 \mathrm{~g} / \mathrm{L}$ depending on the group, $41.0-43.5 \%$ iron deficiency (defined as cord blood serum ferritin $<75 \mu \mathrm{g} / \mathrm{L}$ or zinc protoporphyrin $/ \mathrm{heme}>118 \mu \mathrm{mol} / \mathrm{mol}$ heme, which is the U.S. $90^{\text {th }}$ percentile), mean corpuscular volume $102-103 \mathrm{fL}$, serum ferritin 113-116 $\mathrm{\mu g} / \mathrm{L}$, zinc protoporphyrin/heme 94.3-97.8 $\mu \mathrm{mol} / \mathrm{mol}$ heme, serum transferrin receptor $29.5-31.0 \mathrm{nmol} / \mathrm{L}$, body iron $7.31-7.42 \mathrm{mg} / \mathrm{kg}$

\section{Interventions and comparators}

Intervention: The intervention was iron from supplements consumed during infancy and toddlerhood. The form, dosage, and intervention periods are described below.

Form:

- Eight studies provided iron in the form of ferrous sulfate ${ }^{1,3-6,8-10}$

- Lozoff et $\mathrm{al}^{7}$ provided iron proteinsuccinylate

- Capozzi et $\mathrm{al}^{2}$ did not report the form of iron

Dosage:

- The most common dosage of iron provided by the supplements was $1 \mathrm{mg} / \mathrm{d}$ per $\mathrm{kg}$ of infant body weight (i.e., $1 \mathrm{mg} / \mathrm{kg} / \mathrm{d}$ ) $1-4,7$

- One study provided a different dosage dependent on infant body weight: $2 \mathrm{mg} / \mathrm{kg} / \mathrm{d}^{3}$

- Five studies provided dosages not dependent on infant body weight:

○ $6.6 \mathrm{mg} / \mathrm{d}^{8}$

○ $7 \mathrm{mg} / \mathrm{d}^{10}$

○ $7.5 \mathrm{mg} / \mathrm{d}^{5,9}$

○ $10 \mathrm{mg} / \mathrm{d}^{6}$ 
Intervention period:

The intervention period began as early as 1 month of age and as late as 6 to 18 months of age, and lasted between 1.5 and 7.5 months in duration (Table 1).

Table 1. Summary of the intervention periods, according to baseline age of infants and the duration of iron supplementation

\begin{tabular}{|c|c|}
\hline $\begin{array}{l}\text { Intervention periods, } \\
\text { from youngest to oldest baseline age }\end{array}$ & $\begin{array}{l}\text { Intervention periods, } \\
\text { from shortest to longest duration }\end{array}$ \\
\hline $\begin{array}{l}1 \text { to } 5.5-6 \text { months } \\
6 \text { weeks to } 9 \text { months }\end{array}$ & $\begin{array}{l}1.5 \text { months } \\
\left(6 \text { to } 7.5 \text { months }^{8}\right)\end{array}$ \\
\hline 4 to 6 months ${ }^{6}$ & $\begin{array}{l}2 \text { months } \\
\left(4 \text { to } 6 \text { months }{ }^{6}\right)\end{array}$ \\
\hline $\begin{array}{l}4 \text { to } 9 \text { months } \\
5-7 \text { to } 9-11 \text { months }^{3}\end{array}$ & $\begin{array}{l}3 \text { months } \\
\left(6 \text { to } 9 \text { months }{ }^{4}\right)\end{array}$ \\
\hline $\begin{array}{l}6 \text { to } 7.5 \text { months }^{8} \\
6 \text { to } 9 \text { months }^{4}\end{array}$ & $\begin{array}{l}4 \text { months } \\
\left(5-7 \text { to } 9-11 \text { months }^{3}\right)\end{array}$ \\
\hline \multirow[t]{4}{*}{ 6-18 months to $12-24$ months $^{1}$} & $\begin{array}{l}4.5 \text { months } \\
\left(1 \text { to } 5.5 \text { months }{ }^{10}\right)\end{array}$ \\
\hline & $\begin{array}{l}\mathbf{5} \text { months } \\
\left(1 \text { to } 6 \text { months }{ }^{5}\right. \\
\left.4 \text { to } 9 \text { months }^{2,4,9}\right)\end{array}$ \\
\hline & $\begin{array}{l}6 \text { months } \\
\left(6-18 \text { to } 12-24 \text { months }^{1}\right)\end{array}$ \\
\hline & $\begin{array}{l}7.5 \text { months } \\
\left(6 \text { weeks to } 9 \text { months }^{7}\right)\end{array}$ \\
\hline
\end{tabular}

\section{Comparator}

Study comparators can be categorized into 3 groups:

1. No iron: 3 studies compared infants given iron supplements with infants in a control group given no iron, $, 6,6,9$ and 4 studies compared infants given iron supplements with infants given a placebo. ${ }^{4,5,7,10}$

2. Different amount of iron from supplements: 3 studies compared infants given iron supplements with infants given a different dosage or duration of iron supplements. ${ }^{1,3,4}$

Different dosage:

- $25 \mathrm{mg} / \mathrm{wk}$ (compared to the intervention dosages of $1 \mathrm{mg} / \mathrm{kg} / \mathrm{d}^{1,3}$ and $2 \mathrm{mg} / \mathrm{kg} / \mathrm{d}^{3}$ )

- $2 \mathrm{mg} / \mathrm{kg} / \mathrm{d}$ (compared to the intervention dosage of $1 \mathrm{mg} / \mathrm{kg} / \mathrm{d}^{3}$ )

Different duration:

- $1 \mathrm{mg} / \mathrm{kg} / \mathrm{d}$ from 6 to 9 months compared to $1 \mathrm{mg} / \mathrm{kg} / \mathrm{d}$ from 4 to 9 months ${ }^{4}$ 
3. Iron from fortified foods: 3 studies compared infants given iron from supplements with infants given iron from fortified foods. ${ }^{2,8,9}$

- Capozzi et $\mathrm{al}^{2}$ had comparison groups that were (a) fed human milk exclusively for 5-6 months and weaned with iron-fortified food, and (b) fed iron-fortified infant formula for 56 months and weaned with iron-fortified food [compared to an intervention group fed human milk exclusively for $5-6$ months and given $1 \mathrm{mg} / \mathrm{kg} / \mathrm{d}$ iron supplement from 4 to 9 months (complementary foods for the intervention group were not described)].

- Szymlek-Gay et al ${ }^{8}$ had comparison groups fed (a) high-iron infant formula (dosage of $6.6 \mathrm{mg} / \mathrm{d}$ ), and (b) low-iron infant formula (dosage of $1.3 \mathrm{mg} / \mathrm{d}$ ) (compared to an intervention group fed no-added-iron formula and iron supplementation at a dosage of $6.6 \mathrm{mg} / \mathrm{d})$.

- Ziegler et al ${ }^{9}$ had a comparison group fed iron-fortified cereal at an estimated dosage of $7 \mathrm{mg} / \mathrm{d}$ (compared to the intervention group given iron supplements at a dosage of 7.5 $\mathrm{mg} / \mathrm{d})$.

\section{Outcomes}

Six studies reported measures of change in size from birth or baseline to follow-up, and 7 studies reported measures of attained size at follow-up (Table 2). Measures of attained size in the studies by Hacihamdioglu et al, ${ }^{6}$ Ziegler et al, ${ }^{10}$ and Lozoff et al ${ }^{7}$ should be interpreted with caution. In these 3 studies, there were baseline differences in size between groups and the differences were not controlled for in the analyses. Measures of attained size in the in the study by Cappozi et $\mathrm{al}^{2}$ should also be interpreted with caution, because the authors did not report any assessments of differences in baseline size between groups.

Table 2. Summary of the outcome measures, according to measures of change in size from birth or baseline to follow-up and measures of attained size at follow-up

\begin{tabular}{lll}
\hline $\begin{array}{l}\text { Intervention periods, } \\
\text { from shortest to longest }\end{array}$ & $\begin{array}{l}\text { Outcome measures of } \\
\text { change in size from birth or } \\
\text { baseline to follow-up }\end{array}$ & $\begin{array}{l}\text { Outcome measures of } \\
\text { attained size at follow-up }\end{array}$
\end{tabular}

\section{5 months}

From 6 to 7.5 months $^{8}$ 1.5-month change in: weight weight-for-age z-score length length-for-age z-score head circumference head circumference-for-age z-score knee-heel length (from 6 to 7.5 months)

\section{2 months}

From 4 to 6 months $^{6}$
At 6 months:

Weight

height $^{*}$

head circumference 
Intervention periods,

from shortest to longest

3 months

From 6 to 9 months ${ }^{4}$
Outcome measures of

change in size from birth or

baseline to follow-up
Outcome measures of

attained size at follow-up 2-month change in:

weight

length

head circumference

(from 4 to 6 months)

3-month change in:

weight

length

head circumference

(from 6 to 9 months)

5-month change in:

weight

length

head circumference

(from 4 to 9 months)

\section{4 months}

From 5-7 to 9-11 months ${ }^{3}$

\section{4-month change in:} weight

weight-for-age z-score

length

length-for-age z-score

weight-for-length z-score

(from 5-7 to 9-11 months)

\section{5 months}

From 1 to 5.5 months $^{10}$

\section{5 months \\ From 1 to 6 months $^{5}$ \\ From 4 to 9 months $2,4,9$}

\section{5-month change in:} weight length

(from 1 to 5.5 months)

\section{2-month change in:} weight

length

head circumference

[from 4 to 6 months ${ }^{4}$ ]

3-month change in:

weight

length

head circumference

[from 6 to 9 months $^{4}$ ]

5-month change in:

weight

length

head circumference

[from 4 to 9 months ${ }^{4,9}$ ]

\section{6 months}

From 6-18 to $12-24$ months ${ }^{1}$
At 12-24 months:

weight

weight-for-age z-score

height

height-for-age z-score*

weight-for-height z-score *

BMI z-score 
Intervention periods, from shortest to longest

7.5 months

From 6 weeks to 9 months ${ }^{7}$
Outcome measures of change in size from birth or baseline to follow-up
Outcome measures of attained size at follow-up 9-month change in: weight length (from birth to 9 months)
At 9 months:

weight-for-age z-score height-for-age $z$-score ${ }^{*}$ weight-for-height z-score* head circumference $z$-score

"The authors used the term "height" however it may be "length" given the age of the participants

\section{Synthesis and assessment ${ }^{\mathrm{iii}}$ of the evidence}

This evidence synthesis will focus on analyses that report growth (i.e., change in size from birth or baseline to follow-up) or attained size if the study groups were similar in size at baseline or the authors adjusted for size at baseline. Two studies reported measures of attained size among infants who were significantly different in size at baseline for at least some of their analyses, ${ }^{6,10}$ and 1 study did not report whether infants differed in size at baseline. ${ }^{2}$ The synthesis and assessment of the remaining evidence follows.

\section{Infants given iron from supplements compared with infants not given iron from supplements or infants given a placebo}

Consistency: The evidence had moderate consistency.

Four studies examined differences in growth between infants given iron from supplements and infants given either no iron from supplements or a placebo. Three of the 4 studies reported significant differences in growth between the comparison groups, although the growth outcomes that differed between groups varied between studies:

- Ziegler et al ${ }^{9}$ compared infants given $7.5 \mathrm{mg} / \mathrm{d}$ of iron from supplements from 4 to 9 months of age with infants in a control group who were given neither a supplement nor a placebo. Infants in the iron supplement group had significantly smaller gains in weight and length from 4 to 9 months than infants in the control group.

- Dewey et al ${ }^{4}$ compared Swedish infants given $1 \mathrm{mg} / \mathrm{kg} / \mathrm{d}$ of iron for 5 months (i.e., from 4 to 9 months of age) and for 3 months (i.e., placebo from 4 to 6 months of age and then $1 \mathrm{mg} / \mathrm{kg} / \mathrm{d}$ of iron from 6 to 9 months of age) with infants given a placebo from 4 to 9 months of age. Infants supplemented from 4 to 9 months of age had a significantly lower change in length from 6 to 9 months than infants given a placebo from 4 to 9 months; however, change in length over the entire 4- to 9-month period was not significantly different between groups. Infants supplemented from 4 to 9 months also had a significantly lower change in head

\footnotetext{
iii A detailed description of the methodology used for grading the strength of the evidence is available on the NESR website: https://nesr.usda.gov/2020-dietary-guidelines-advisory-committee-systematic-reviews and in Part C of the following reference: Dietary Guidelines Advisory Committee. 2020. Scientific Report of the 2020 Dietary Guidelines Advisory Committee: Advisory Report to the Secretary of Agriculture and the Secretary of Health and Human Services. U.S. Department of Agriculture, Agricultural Research Service, Washington, DC.
} 
circumference from 4 to 6 months and across the whole 4- to 9-month period than infants in the placebo group. There were no significant differences in weight gain between groups. There were also no significant differences in any measures of growth between infants given a placebo from 4 to 6 months preceding iron supplementation from 6 to 9 months compared with infants given a placebo from 4 to 9 months.

- Ziegler et al ${ }^{10}$ compared infants given $7 \mathrm{mg} / \mathrm{d}$ of iron for 4.5 months with infants given a placebo. Among females, those given iron gained significantly less weight from 1 to 5.5 months than those given placebo. Among males, weight gain did not differ between intervention groups. There were no significant group differences in length gain in either females or males.

- In contrast to the 3 studies above, Lozoff et $\mathrm{al}^{7}$ reported no significant differences in growth between comparison groups. The study compared infants given about $1 \mathrm{mg} / \mathrm{kg} / \mathrm{d}$ of iron from 6 weeks to 9 months of age with infants given a placebo and stratified the analyses based on maternal prenatal iron supplementation. There were no significant differences in weight or length gain from birth to 9 months.

Four studies examined differences in attained size among infants who were similar in size at baseline. Three of these 4 studies also examined growth outcomes, as described above. One of the 4 studies reported significant differences between infants given iron from supplements and infants given either no iron from supplements or a placebo:

- Consistent with the significant findings for growth described above, Ziegler et al ${ }^{10}$ reported that among females, those given $7 \mathrm{mg} / \mathrm{d}$ of iron from 1 to 5.5 months of age weighed less at 5.5 months than those given a placebo, even though groups were similar at baseline. There was no significant group difference in length at 5.5 months among females. (Findings in males are not discussed here because male infants in the supplementation group were smaller at birth and baseline than male infants in the placebo group.)

- The remaining 3 studies found no significant differences in attained size.

- Consistent with the nonsignificant findings for growth described above, Lozoff et al ${ }^{7}$ reported no significant differences in weight-for-age z-score, height-for-age z-score, weight-for-height z-score, or head circumference z-score at 9 months between comparison groups.

- Inconsistent with the significant findings for growth described above, Ziegler et al ${ }^{9}$ found no significant differences in weight or length at 9 months, reported by sex, between infants given $7.5 \mathrm{mg} / \mathrm{d}$ of iron from 4 to 9 months, compared with no iron supplementation and no placebo. This inconsistency may be due to the smaller analysis groups; the significant findings for growth, above, included the full sample whereas the nonsignificant findings for size were stratified into smaller groups by sex.

- Friel et al ${ }^{5}$ compared infants given $7.5 \mathrm{mg} / \mathrm{d}$ of iron from 1 to 6 months of age with infants given a placebo, and found no significant differences in weight, length, or head circumference measured at $3.5,6$, and 12 months.

In summary, of the 5 studies described above, 3 reported significant differences between intervention groups in one or more growth outcomes (all in the same direction, i.e., slower growth among infants given iron supplements) and 2 did not. There are several possible explanations for this inconsistency.

First, the study populations differed in several characteristics that may be related to risk of iron deficiency and therefore the potential impact of iron supplements on growth. Four studies were 
conducted among populations with medium to high average socio-economic or educational status, $4,5,9,10$ whereas the study by Lozoff et $\mathrm{al}^{7}$ was conducted in rural China and only about onethird of mothers had a high-school education or greater (see Generalizability). Risk of iron deficiency appeared to be greater in the study by Lozoff et al, ${ }^{7}$ based on average hemoglobin and serum ferritin concentrations at 9 months of age in the control or placebo groups. For hemoglobin, those values were $111 \mathrm{~g} / \mathrm{L}$ in the study by Lozoff et al ${ }^{7}$ compared to 116,115 and $114 \mathrm{~g} / \mathrm{L}$ in the studies by Ziegler et al, ${ }^{9}$ Ziegler et al, ${ }^{10}$ and Dewey et al, ${ }^{\mathrm{iv}}$ respectively. For serum ferritin those values were $11 \mu \mathrm{g} / \mathrm{L}$ in the study by Lozoff et al. compared to 28,43 and $23 \mu \mathrm{g} / \mathrm{L}$ in the studies by Ziegler et al, ${ }^{9}$ Ziegler et al, ${ }^{10}$ and Dewey et al, ${ }^{\text {iv }}$ respectively. For the study by Friel et al, ${ }^{5}$ this information is not available, but the investigators reported that average serum ferritin in the placebo group was $27 \mu \mathrm{g} / \mathrm{L}$ at 6 months and $14 \mu \mathrm{g} / \mathrm{L}$ at 12 months.

Second, the studies differed in the extent to which the infants were supplemented with ironfortified infant formula or iron-rich foods, which may have obscured effects of iron supplementation on growth. Although all studies enrolled infants who were initially breastfed, 3 reported that a substantial proportion of infants ceased breastfeeding and/or were supplemented with infant formula, ${ }^{5,9,10}$ whereas Dewey et al ${ }^{4}$ enrolled mothers who intended to exclusively breastfeed until 6 months (except for small "tastes" of low-iron foods) and to continue breastfeeding until at least 9 months; in the study by Lozoff et al, ${ }^{7}$ investigators reported that more than $80 \%$ of infants were still breastfeeding at 9 months, and $>50 \%$ received breast milk as the sole milk source.

Lastly, the timing of iron supplementation differed among studies. Of the 3 studies that began iron supplementation at 1 month or 6 weeks, 2 did not report significant differences in growth between intervention groups, ${ }^{5,7}$ and the third reported significant group differences in growth among females but not among male infants. ${ }^{10}$ The two studies that began iron supplementation at about 4 months both showed significant group differences in growth. ${ }^{4,9}$

Precision: The evidence had limited precision.

There was a small number of studies overall. Only Lozoff et $\mathrm{al}^{7}$ reported a power analysis related to growth outcomes, so it is unclear whether all studies had sufficient statistical power for all of the analyses of interest.

Directness: The evidence had moderate directness.

Three of the studies reported objectives that included assessing the effect of iron supplementation on infant growth ${ }^{4,5,7}$ and 2 studies did not. 9,10

Generalizability: The evidence had moderate generalizability.

Four studies were likely to be generalizable to healthy infants from the U.S. ${ }^{4,5,9,10}$ whereas 1 study ${ }^{7}$ had limited generalizability to healthy infants from the U.S. There is limited generalizability to iron supplementation and its effect on growth and size outside of infancy.

Risk of bias: There is a moderate likelihood that the design and conduct of the studies have prevented or minimized bias.

The evidence is from randomized controlled trials. Further, this evidence synthesis does not examine differences in attained size between randomization groups that differed in size at baseline (i.e., with a failure of randomization). There were some risks of bias, which differed

iv Reported in: Domellöf, M., Cohen, R. J., Dewey, K. G., Hernell, O., Rivera, L. L., \& Lönnerdal, B. (2001). Iron supplementation of breast-fed Honduran and Swedish infants from 4 to 9 months of age. The Journal of pediatrics, 138(5), 679-687. 
between studies (Table 4).

Publication bias: In addition to the graded elements of the assessment of the evidence, above, it is important to give consideration to publication bias. There is not a strong indication of publication bias. Although only 5 included studies examined infants given iron from supplements compared with infants not given iron from supplements or infants given a placebo, they presented evidence with some variability. As described above, 3 of the 5 studies reported significant differences between intervention groups in one or more growth outcomes although the growth outcomes that differed between groups varied between studies.

\section{Infants given iron from supplements compared with infants given a different dosage or duration of iron from supplements}

Only 3 studies examined infants given iron from supplements compared with infants give a different dosage or duration of iron from supplements. The consistency and precision of the evidence cannot be adequately assessed due to the heterogeneity of the interventions. The risk of bias of the 3 studies is summarized in (Table 4Table 5).

Two studies examined growth in infants given different dosages or durations of iron from supplements. One reported a significant difference in head circumference growth between infants given iron supplements for different durations, and the second reported no significant differences in growth between infants given different dosages of iron from supplements:

- Dewey et al ${ }^{4}$ compared Swedish infants given iron supplements at a dosage of $1 \mathrm{mg} / \mathrm{kg} / \mathrm{d}$ for 5 compared to 3 months. Infants supplemented from 4 to 9 months of age had a significantly lower change in head circumference from 4 to 9 months of age than infants given a placebo from 4 to 6 months followed by supplementation from 6 to 9 months of age. Weight and length gain did not differ significantly between these two groups.

- da Silva et al ${ }^{3}$ found no significant differences in growth from 5-7 to 9-11 months of age between infants given: (a) a daily dosage of $1 \mathrm{mg} / \mathrm{kg}$ vs a daily dosage of $2 \mathrm{mg} / \mathrm{kg}$, (b) a daily dosage of $1 \mathrm{mg} / \mathrm{kg}$ vs a weekly dosage of $25 \mathrm{mg}$, or (c) a daily dosage of $2 \mathrm{mg} / \mathrm{kg}$ vs a weekly dosage of $25 \mathrm{mg}$ from 5-7 to 9-11 months of age.

One study examined attained size in infants who were similar in size at baseline, and did not find any significant differences between infants given different dosages of iron from supplements:

- Azeredo et al ${ }^{1}$ found no significant differences in attained size at 12-24 months of age between children given a daily dosage of $1 \mathrm{mg} / \mathrm{kg}$ and children given a weekly dosage of 25 $\mathrm{mg}$ from 6-18 to 12-24 months of age.

\section{Infants given iron from supplements compared with infants given iron from fortified foods}

Only 2 studies examined infants given iron from supplements compared with infants given iron from fortified foods. The consistency and precision of the evidence cannot be adequately assessed due to the heterogeneity of the interventions. The risk of bias of the 2 studies is summarized in Table 4.

Both studies examined growth or attained size in infants given iron from supplements compared with infants given iron from fortified foods. One of the 2 studies reported a significant difference in growth:

- Szymlek-Gay et al ${ }^{8}$ found that infants given $6.6 \mathrm{mg} / \mathrm{d}$ of iron as a supplement from 6 to 7.5 months of age had a significantly greater change in head circumference during the intervention period than infants given the same amount of iron in a high-iron infant formula. 
There were no significant differences in other measures of growth (i.e., head circumferencefor-age z-score, weight, weight-for-age z-score, length, length-for-age z-score, and knee-heel length). Further, there were no significant differences in any growth measures between infants fed $6.6 \mathrm{mg} / \mathrm{d}$ of iron as a supplement and infants fed $1.3 \mathrm{mg} / \mathrm{d}$ of iron in a low-iron infant formula.

- Ziegler et al $^{9}$ reported no significant differences in growth (i.e., weight gain and length gain from 4 to 9 months of age, reported by sex) or attained size (weight and length at 9 months of age, reported by sex) between infants given $7.5 \mathrm{mg} / \mathrm{d}$ of iron from supplements and infants who consumed an estimated $7 \mathrm{mg} / \mathrm{d}$ of iron from iron-fortified cereal from 4 to 9 months of age.

\section{Conclusion}

Given this synthesis and assessment of the evidence, we conclude that:

- Moderate evidence indicates that human milk-fed infants who are supplemented with iron do not have greater growth, and may have slower growth, than human milk-fed infants not supplemented with iron.

- Insufficient evidence is available to determine the relationship between iron from supplements consumed during infancy and body composition during infancy.

- Insufficient evidence is available to determine the relationship between iron from supplements consumed during infancy and growth, size, and body composition beyond 12 months of age.

- Insufficient evidence is available to determine the relationship between iron from supplements consumed after 12 months of age and growth, size, and body composition. 
Table 3. Evidence examining the relationship between iron from supplements consumed during infancy and toddlerhood and growth, size, and body composition*

\begin{tabular}{|c|c|c|c|c|}
\hline $\begin{array}{l}\text { Article } \\
\text { Study design } \\
\text { Country }\end{array}$ & Iron from supplements intervention vs comparator ${ }^{\dagger}$ & $\begin{array}{l}\text { Growth, size, and body composition } \\
\text { outcome }^{\ddagger}\end{array}$ & Significant findings & $\begin{array}{l}\text { Nonsignificant } \\
\text { findings }\end{array}$ \\
\hline \multicolumn{5}{|c|}{ Iron from supplement compared with no iron or placebo } \\
\hline \multirow[t]{9}{*}{$\begin{array}{l}\text { Capozzi } 2011^{2} \\
\text { PC or NRCT or } \\
\text { RCT } \S \\
\text { Italy }\end{array}$} & $\begin{array}{l}\text { EBF } 5-6 \mathrm{mo} \text { and weaned with non-iron fortified food vs } \\
\text { EBF } 5-6 \mathrm{mo} \text { (weaning CF NR) and given iron } \\
\text { supplement from } 4 \text { to } 9 \mathrm{mo}(1 \mathrm{mg} / \mathrm{kg} / \mathrm{d})\end{array}$ & $\begin{array}{l}\text { Weight }(\text { mean } \pm S D, k g) \\
\text { In males }(N=15,14) \\
\text { at } 6 \text { mo }\end{array}$ & $\begin{array}{l}7.2 \pm 0.24 \text { vs } 7.2 \pm 0.8 \\
p<0.05\end{array}$ & . \\
\hline & & at $12 \mathrm{mo}$ & . & $\begin{array}{l}9.2 \pm 0.9 \text { vs } 9.4 \pm \\
1.5 ; \text { NS }\end{array}$ \\
\hline & & at $18 \mathrm{mo}$ & . & $\begin{array}{l}11.8 \pm 1.2 \text { vs } 12.6 \pm \\
0.9 ; \mathrm{NS}\end{array}$ \\
\hline & & at $24 \mathrm{mo}$ & $\begin{array}{l}11.5 \pm 0.9 \text { vs } 12.9 \pm \\
2.1 ; p<0.05\end{array}$ & . \\
\hline & & In females $(\mathrm{N}=20,12)$ & & \\
\hline & & at $6 \mathrm{mo}$ & $\begin{array}{l}6.8 \pm 0.21 \text { vs } 7.2 \pm 0.9 \\
p<0.05\end{array}$ & . \\
\hline & & at $12 \mathrm{mo}$ & . & $\begin{array}{l}8.9 \pm 0.5 \text { vs } 9.1 \pm \\
1.1 ; \mathrm{NS}\end{array}$ \\
\hline & & at $18 \mathrm{mo}$ & . & $\begin{array}{l}10.7 \pm 1.2 \text { vs } 11.9 \pm \\
1.8 ; \mathrm{NS}\end{array}$ \\
\hline & & at $24 \mathrm{mo}$ & $\begin{array}{l}10.9 \pm 1.2 \text { vs } 12.8 \pm \\
1.1 ; p<0.05\end{array}$ & . \\
\hline
\end{tabular}

Length (mean $\pm \mathrm{SD}, \mathrm{cm})$ at $6 \mathrm{mo}$

In males $(\mathrm{N}=15,14)$

at $6 \mathrm{mo}$ 


\section{Article}

Study design Iron from supplements intervention vs comparator ${ }^{\dagger}$

Growth, size, and body composition

outcome $\ddagger$

Significant findings

Nonsignificant

Country

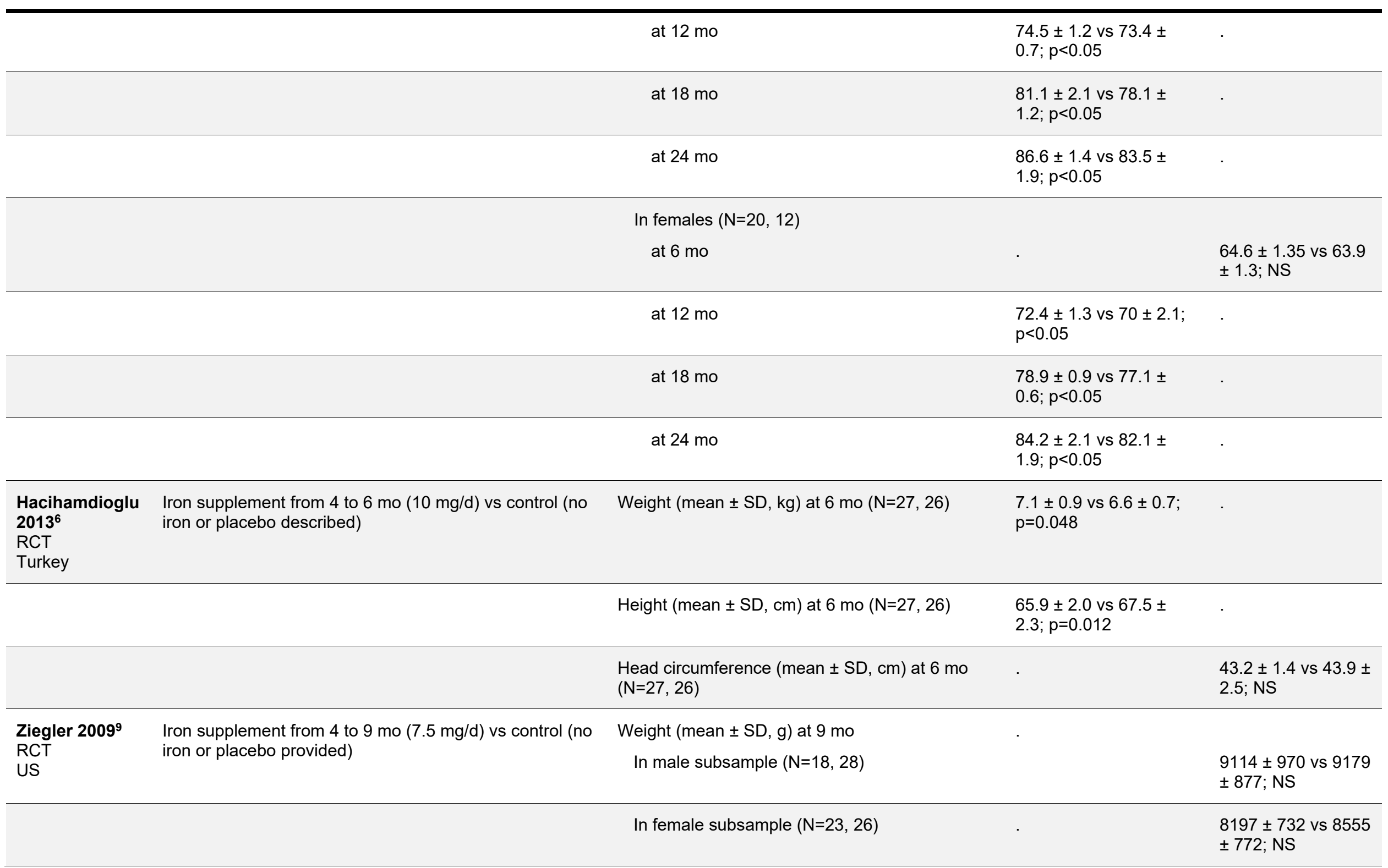




\section{Article}

Study design

Country

\begin{tabular}{|c|c|c|c|c|}
\hline & & $\begin{array}{l}\text { Weight gain (mean } \pm S D, g / d) \text { from } 4 \text { to } 9 \mathrm{mo} \\
(\mathrm{N}=41,54)\end{array}$ & $\begin{array}{l}12.18(\mathrm{SD} N R) \text { vs } 13.58 \\
(\mathrm{SD} N R) ; p=0.027\end{array}$ & . \\
\hline & & In male subsample $(\mathrm{N}=18,28)$ & . & $\begin{array}{l}12.7 \pm 2.39 \text { vs } 13.9 \\
\pm 3.30 ; \text { NS }\end{array}$ \\
\hline & & In female subsample $(\mathrm{N}=23,26)$ & . & $\begin{array}{l}11.6 \pm 3.23 \text { vs } 13.3 \\
\pm 3.39 ; \text { NS }\end{array}$ \\
\hline & & Length (mean $\pm \mathrm{SD}, \mathrm{cm}$ ) at $9 \mathrm{mo}$ & . & \\
\hline & & In male subsample $(\mathrm{N}=18,28)$ & & $\begin{array}{l}72.0 \pm 1.92 \text { vs } 71.5 \\
\pm 1.84 ; \text { NS }\end{array}$ \\
\hline & & In female subsample $(\mathrm{N}=23,26)$ & . & $\begin{array}{l}69.2 \pm 1.79 \text { vs } 70.1 \\
\pm 1.96 ; \text { NS }\end{array}$ \\
\hline & & $\begin{array}{l}\text { Length gain }(\text { mean } \pm S D, m m / d) \text { from } 4 \text { to } 9 \mathrm{mo} \\
(\mathrm{N}=41,54)\end{array}$ & $\begin{array}{l}0.484 \text { (SD NR) vs } 0.519 \\
\text { (SD NR); } p=0.011\end{array}$ & . \\
\hline & & In male subsample $(\mathrm{N}=18,28)$ & . & $\begin{array}{l}0.50 \pm 0.071 \text { vs } \\
0.51 \pm 0.060 ; \mathrm{NS}\end{array}$ \\
\hline & & In female subsample $(\mathrm{N}=23,26)$ & . & $\begin{array}{l}0.47 \pm 0.062 \text { vs } \\
0.52 \pm 0.072 ; \mathrm{NS}\end{array}$ \\
\hline \multicolumn{5}{|c|}{ Iron from supplement compared to placebo } \\
\hline \multirow[t]{5}{*}{$\begin{array}{l}\text { Dewey } 2002^{4} \\
\text { RCT } \\
\text { Sweden }\end{array}$} & $\begin{array}{l}\text { Placebo from } 4 \text { to } 9 \mathrm{mo} \text { vs Placebo from } 4 \text { to } 6 \mathrm{mo} \text { and } \\
\text { iron supplement from } 6 \text { to } 9 \mathrm{mo}(1 \mathrm{mg} / \mathrm{kg} / \mathrm{d})\end{array}$ & $\begin{array}{l}\text { Weight gain (mean } \pm \mathrm{SE}, \mathrm{g}) \\
\text { from } 4 \text { to } 6 \mathrm{mo}(\mathrm{N}=36,34)\end{array}$ & . & $\begin{array}{l}967 \pm 52 \text { vs } 860 \pm \\
54 ; \text { NS }\end{array}$ \\
\hline & & from 6 to $9 \mathrm{mo}(\mathrm{N}=36,30)$ & . & $\begin{array}{l}1175 \pm 69 \text { vs } 1137 \\
\pm 75 ; \text { NS }\end{array}$ \\
\hline & & from 4 to $9 \mathrm{mo}(\mathrm{N}=36,30)$ & t & $\begin{array}{l}2134 \pm 92 \text { vs } 2013 \\
\pm 100 ; \text { NS }\end{array}$ \\
\hline & & Length gain (mean $\pm \mathrm{SE}, \mathrm{cm})$ & & \\
\hline & & from 4 to $6 \mathrm{mo}(\mathrm{N}=36,34)$ & . & $\begin{array}{l}3.07 \pm 0.15 \text { vs } 3.02 \\
\pm 0.15 ; \text { NS }\end{array}$ \\
\hline
\end{tabular}
outcome

Significant findings

Nonsignificant

findings
Growth, size, and body composition
Weight gain (mean $\pm S D, g / d$ ) from 4 to $9 \mathrm{mo}$
$12.7 \pm 2.39$ vs 13.9

$11.6 \pm 3.23$ vs 13.3 $\pm 3.39 ; \mathrm{NS}$

$72.0 \pm 1.92$ vs 71.5

$9.2 \pm 1.79$ vs 70.1 


\section{Article}

Study design Iron from supplements intervention vs comparator ${ }^{\dagger}$

Growth, size, and body composition

outcome ${ }^{\ddagger}$

Significant findings

Nonsignificant

Country

from 6 to $9 \mathrm{mo}(\mathrm{N}=36,30)$

$4.68 \pm 0.19$ vs 4.22

\pm 0.21 ; NS

from 4 to $9 \mathrm{mo}(\mathrm{N}=36,30)$

$7.79 \pm 0.21$ vs 7.14

$\pm 0.23 ; \mathrm{NS}$

Change in head circumference (mean $\pm \mathrm{SE}, \mathrm{cm}$ )

from 4 to $6 \mathrm{mo}(\mathrm{N}=36,34)$

$1.78 \pm 0.06$ vs 1.74

$\pm 0.06 ;$ NS

from 6 to $9 \mathrm{mo}(\mathrm{N}=36,30)$

$2.11 \pm 0.07$ vs 2.09

$\pm 0.07 ;$ NS

from 4 to $9 \mathrm{mo}(\mathrm{N}=36,30)$

$3.88 \pm 0.08$ vs 3.84

$\pm 0.09 ;$ NS

Placebo from 4 to 9 mo vs Iron supplement from 4 to 9

$\mathrm{mo}(1 \mathrm{mg} / \mathrm{kg} / \mathrm{d})$

Weight gain (mean $\pm \mathrm{SE}, \mathrm{g}$ )

from 4 to $6 \mathrm{mo}(\mathrm{N}=36,31)$

$967 \pm 52$ vs $880 \pm$

57 ; NS

from 6 to $9 \mathrm{mo}(\mathrm{N}=36,30)$

$1175 \pm 69$ vs 1054

\pm 75 ; NS

from 4 to $9 \mathrm{mo}(\mathrm{N}=36,30)$

$2134 \pm 92$ vs 1925

$\pm 101 ;$ NS

Length gain (mean $\pm \mathrm{SE}, \mathrm{cm}$ )

from 4 to $6 \mathrm{mo}(\mathrm{N}=36,31)$

$3.07 \pm 0.15$ vs 3.37

$\pm 0.16 ;$ NS

from 6 to $9 \mathrm{mo}(\mathrm{N}=36,30)$

$4.68+0.19$ vs $4.00 \pm$

$0.21 ; p=0.02$

from 4 to $9 \mathrm{mo}(\mathrm{N}=36,30)$

$7.79 \pm 0.21$ vs 7.31

\pm 0.23 ; NS

Change in head circumference (mean $\pm \mathrm{SE}, \mathrm{cm}$ )

from 4 to $6 \mathrm{mo}(\mathrm{N}=36,31)$

$1.78 \pm 0.06$ vs $1.57 \pm$

$0.06 ; p<0.05$ 


\section{Article}

Study desig

Iron from supplements intervention vs comparator ${ }^{\dagger}$

Growth, size, and body composition

outcome $\ddagger$

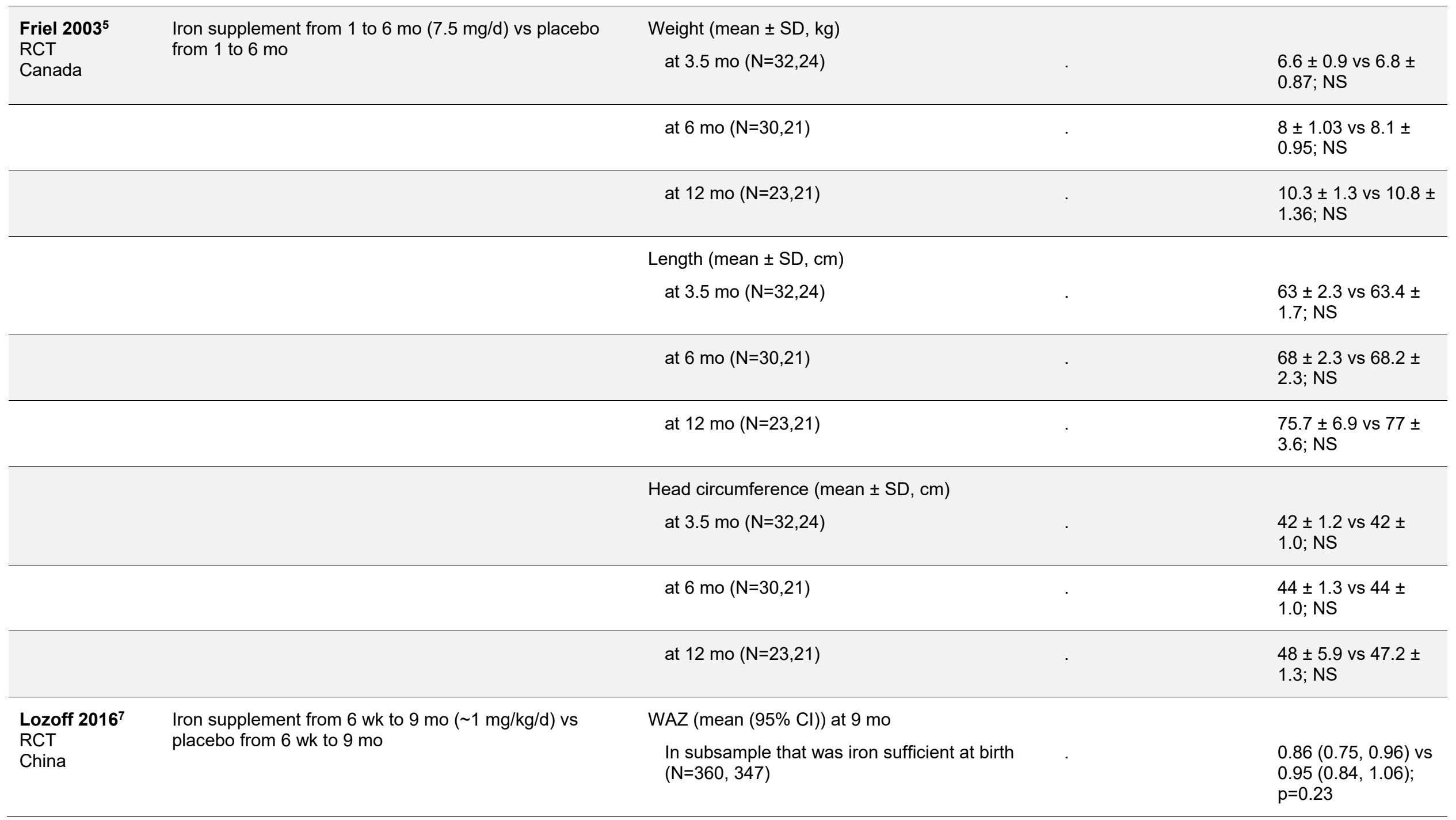




\section{Article}

In subsample whose mothers received prenatal iron $(\mathrm{N}=327,316)$

$0.97(0.86,1.08)$ $0.92(0.81,1.03)$ NS

In subsample whose mothers received prenatal placebo $(\mathrm{N}=321,312)$

$0.80(0.69,0.91) \mathrm{v}$ $0.89(0.77,1.00)$; NS

Weight gain (mean $(95 \% \mathrm{Cl}), \mathrm{g})$ from birth to 9 mo

In subsample that was iron sufficient at birth $(\mathrm{N}=360,347)$

$6204(6088,6321)$

vs $6335(6214$ $6455) ; p=0.13$

In subsample whose mothers received prenatal iron $(\mathrm{N}=327,316)$

$6356(6235,6477)$

vs $6354(6231$

6477)

In subsample whose mothers received prenatal placebo $(\mathrm{N}=321,312)$

$6161(6039,6283)$

vs $6270(6146$

6395)

\section{$\mathrm{HAZ}$ (mean $(95 \% \mathrm{Cl})$ ) at 9 mo}

In subsample that was iron sufficient at birth

$(\mathrm{N}=360,347)$

$0.25(0.14,0.36)$ vs

$0.33(0.22,0.43)$

$\mathrm{p}=0.32$

In subsample whose mothers received prenatal

iron $(\mathrm{N}=327,316)$

$0.33(0.22,0.45)$ vs $0.30(0.18,0.41)$; NS

In subsample whose mothers received prenatal placebo $(\mathrm{N}=321,312)$

Length gain (mean $(95 \% \mathrm{Cl}), \mathrm{cm})$ from birth to 9 mo

In subsample that was iron sufficient at birth $(\mathrm{N}=360,347)$ 


\section{Article}

In subsample whose mothers received prenatal iron $(\mathrm{N}=327,316)$

In subsample whose mothers received prenatal placebo $(\mathrm{N}=321,312)$
$22.7(22.4,23.0)$ vs $22.4(22.1,22.7)$; NS

$22.3(22.1,22.6) \mathrm{v}$ $22.4(22.1,22.7)$; NS

$\mathrm{WHZ}($ mean $(95 \% \mathrm{Cl}))$ at $9 \mathrm{mo}$

In subsample that was iron sufficient at birth $(\mathrm{N}=360,347)$

In subsample whose mothers received prenatal iron $(\mathrm{N}=327,316)$

$1.03(0.91,1.14)$ $1.10(0.98,1.22)$; $\mathrm{p}=0.38$

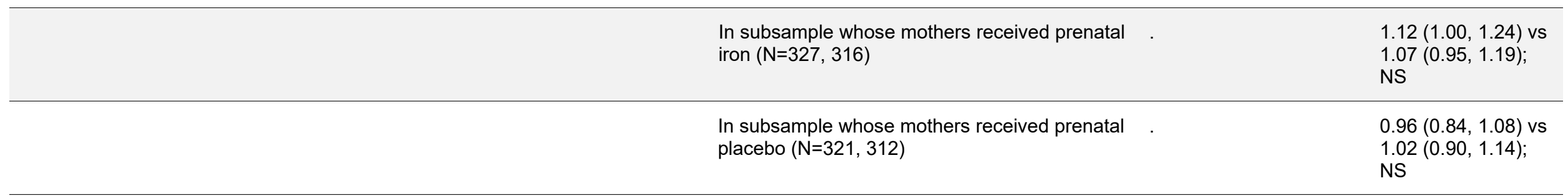

Head circumference z-score (mean $(95 \% \mathrm{Cl}))$ at $9 \mathrm{mo}$

In subsample that was iron sufficient at birth $(\mathrm{N}=360,347)$

$0.06(20.05,0.16)$

vs $0.06(20.08$,

$0.19) ; p=1.00$

In subsample whose mothers received prenatal iron $(\mathrm{N}=327,316)$

$0.13(0.01,0.26)$ vs $0.04(20.08,0.17)$ NS

In subsample whose mothers received prenatal placebo $(\mathrm{N}=321,312)$

$0.01(20.11,0.14)$

vs $0.10(20.02$

$0.23)$; NS

\section{Ziegler $2009^{10}$ \\ RCT \\ Iron supplement from 1 to $5.5 \mathrm{mo}(7 \mathrm{mg} / \mathrm{d})$ vs Placebo from 1 to $5.5 \mathrm{mo}$}

US
Weight (mean \%ile) at 5.5 months

In males $(\mathrm{N}=15,15)$

(mean \%ile) 


\section{Article}

Study design

Country

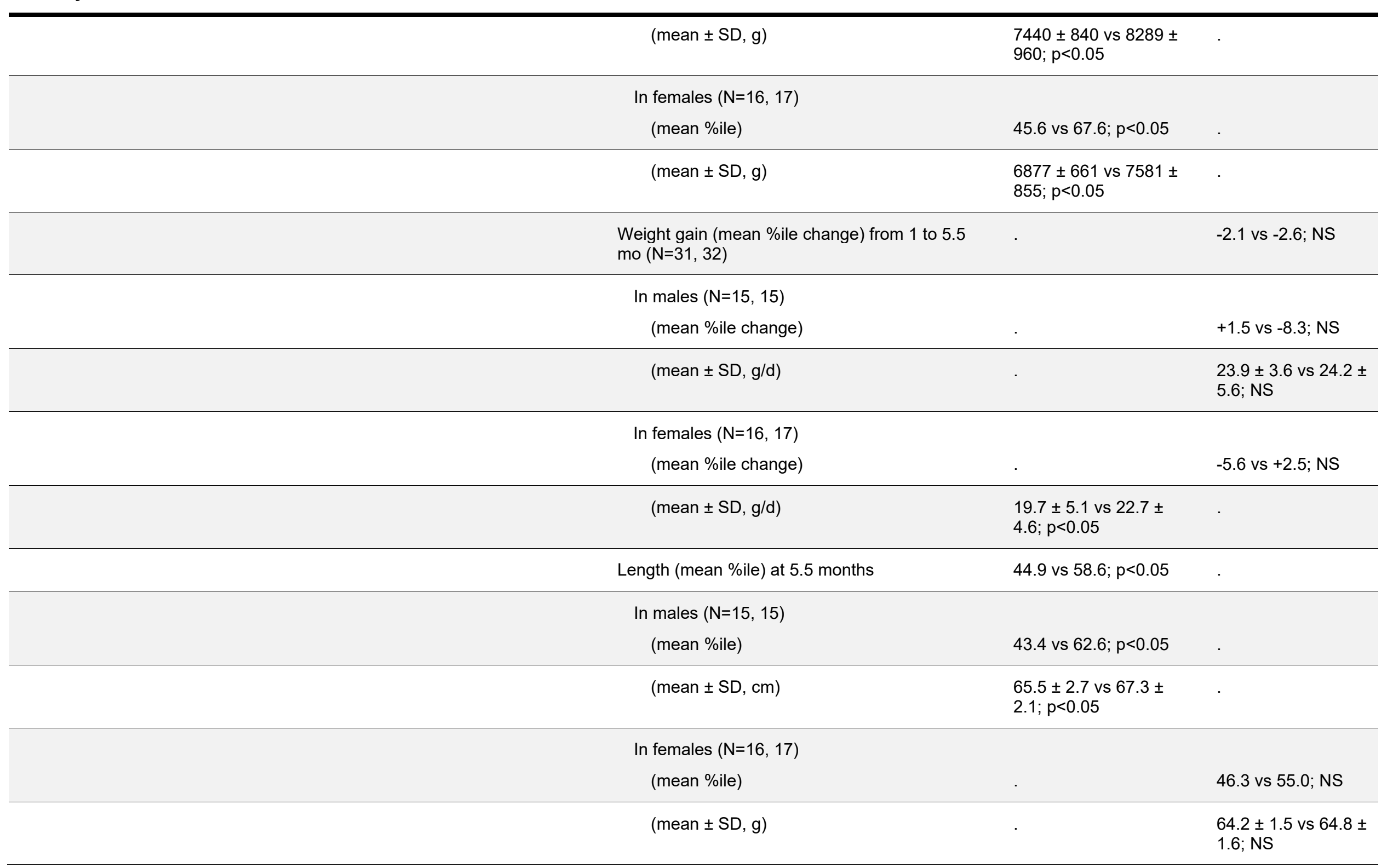

Growth, size, and body composition outcome

\section{Significant findings}

Nonsignificant

findings 


\section{Article}

Study desig

Iron from supplements intervention vs comparator ${ }^{\dagger}$

Growth, size, and body composition

outcome $\ddagger$

\begin{tabular}{|c|c|c|c|}
\hline & & $\begin{array}{l}\text { Length gain (mean \%ile change) from } 1 \text { to } 5.5 \\
\text { mo }\end{array}$ & +0.1 vs $-1.7 ; \mathrm{NS}$ \\
\hline \multicolumn{4}{|c|}{ In males $(\mathrm{N}=15,15)$} \\
\hline & & (mean \%ile change) & +3.7 vs $-1.9 ;$ NS \\
\hline & & $($ mean $\pm \mathrm{SD}, \mathrm{mm} / \mathrm{d})$ & $\begin{array}{l}0.882 \pm 0.098 \text { vs } \\
0.843 \pm 0.103 ; \mathrm{NS}\end{array}$ \\
\hline \multicolumn{4}{|c|}{ In females $(\mathrm{N}=16,17)$} \\
\hline & & (mean \%ile change) & -3.2 vs $-1.6 ;$ NS \\
\hline & & $($ mean $\pm S D, m m / d)$ & $\begin{array}{l}0.786 \pm 0.072 \text { vs } \\
0.792 \pm 0.061 ; \mathrm{NS}\end{array}$ \\
\hline \multicolumn{4}{|c|}{ Iron from supplement compared to different dosage of iron from supplement } \\
\hline \multirow[t]{5}{*}{$\begin{array}{l}\text { Azeredo } 2010^{1} \\
\text { NRCT } \\
\text { Brazil }\end{array}$} & $\begin{array}{l}\text { Daily iron supplement from } 6-18 \mathrm{mo} \text { (mean } 11.5 \mathrm{mo} \text { ) to } \\
12-24 \mathrm{mo}(1 \mathrm{mg} / \mathrm{kg} / \mathrm{d}) \text { vs weekly iron supplement from } 6 \text { - } \\
18 \mathrm{mo}(\mathrm{mean} 11.5 \mathrm{mo}) \text { to } 12-24 \mathrm{mo}(25 \mathrm{mg} / \mathrm{wk})\end{array}$ & Weight (mean $\pm \mathrm{SD}, \mathrm{kg})$ at $12-24 \mathrm{mo}(\mathrm{N}=34,69)$ & $\begin{array}{l}10.46 \pm 1.72 \text { vs } \\
10.21 \pm 1.91 \\
p=0.516\end{array}$ \\
\hline & & Height (mean $\pm \mathrm{SD}, \mathrm{cm})$ at $12-24 \mathrm{mo}(\mathrm{N}=34,69)$ & $\begin{array}{l}80.44 \pm 5.29 \text { vs } \\
79.63 \pm 5.02 \\
p=0.452\end{array}$ \\
\hline & & WAZ $($ mean $\pm S D)$ at $12-24 \mathrm{mo}(\mathrm{N}=34,69)$ & $\begin{array}{l}-0.18 \pm 1.167 \text { vs }- \\
0.26 \pm 1.291 \\
p=0.748\end{array}$ \\
\hline & & $\mathrm{HAZ}($ mean $\pm \mathrm{SD})$ at $12-24 \mathrm{mo}(\mathrm{N}=34,69)$ & $\begin{array}{l}-0.26 \pm 1.214 \text { vs }- \\
0.35 \pm 1.186 \\
p=0.741\end{array}$ \\
\hline & & $\mathrm{WHZ}($ mean $\pm \mathrm{SD})$ at $12-24 \mathrm{mo}(\mathrm{N}=34,69)$ & $\begin{array}{l}-0.15 \pm 0.989 \text { vs }- \\
0.14 \pm 1.275 \\
p=0.993\end{array}$ \\
\hline
\end{tabular}




\section{Article}

Study design

Country
Iron from supplements intervention vs comparator ${ }^{\dagger}$

Iron from supplements intervention vs comp

\section{Growth, size, and body composition}

outcome ${ }^{\ddagger}$

\section{Significant findings}

Nonsignificant

findings

BMlz (mean $\pm \mathrm{SD})$ at $12-24 \mathrm{mo}(\mathrm{N}=34,69)$

$-0.09 \pm 0.996$ vs -

$0.13 \pm 1.316$

$\mathrm{p}=0.869$

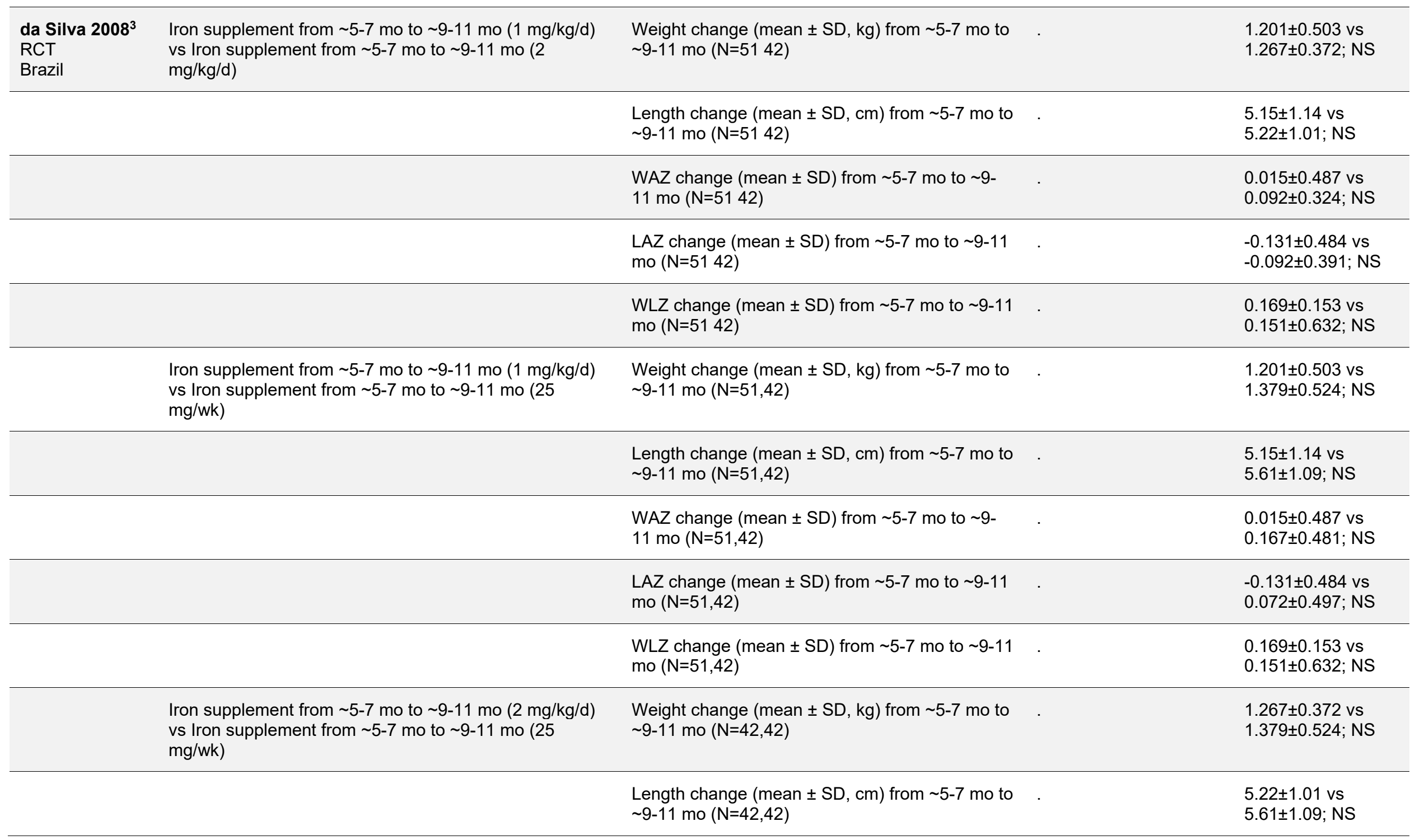




\section{Article}

Study desi

Country

Iron from supplements intervention vs comparator ${ }^{\dagger}$

Growth, size, and body composition

outcome

\begin{tabular}{|c|c|c|c|c|}
\hline & & $\begin{array}{l}\text { WAZ change (mean } \pm S D) \text { from } \sim 5-7 \text { mo to } \sim 9 \text { - } \\
11 \text { mo }(N=42,42)\end{array}$ & . & $\begin{array}{l}0.092 \pm 0.324 \text { vs } \\
0.167 \pm 0.481 ; \mathrm{NS}\end{array}$ \\
\hline & & $\begin{array}{l}\text { LAZ change (mean } \pm S D) \text { from } \sim 5-7 \text { mo to } \sim 9-11 \\
\text { mo }(N=42,42)\end{array}$ & . & $\begin{array}{l}-0.092 \pm 0.391 \text { vs } \\
0.072 \pm 0.497 ; \text { NS }\end{array}$ \\
\hline & & $\begin{array}{l}\text { WLZ change (mean } \pm S D) \text { from } \sim 5-7 \text { mo to } \sim 9-11 \\
\mathrm{mo}(\mathrm{N}=42,42)\end{array}$ & . & $\begin{array}{l}0.151 \pm 0.632 \text { vs } \\
0.151 \pm 0.632 ; \mathrm{NS}\end{array}$ \\
\hline \multirow[t]{11}{*}{$\begin{array}{l}\text { Dewey } 2002^{4} \\
\text { RCT } \\
\text { Sweden }\end{array}$} & $\begin{array}{l}\text { Placebo from } 4 \text { to } 6 \text { mo and iron supplement from } 6 \text { to } 9 \\
\mathrm{mo}(1 \mathrm{mg} / \mathrm{kg} / \mathrm{d}) \text { vs Iron supplement from } 4 \text { to } 9 \mathrm{mo}(1 \\
\mathrm{mg} / \mathrm{kg} / \mathrm{d})\end{array}$ & $\begin{array}{l}\text { Weight gain (mean } \pm S E, g) \\
\text { from } 4 \text { to } 6 \text { mo }(N=34,31)\end{array}$ & . & $\begin{array}{l}860 \pm 54 \text { vs } 880 \pm \\
57 ; \text { NS }\end{array}$ \\
\hline & & from 6 to $9 \mathrm{mo}(\mathrm{N}=30,30)$ & . & $\begin{array}{l}1137 \pm 75 \text { vs } 1054 \\
\pm 75 ; \text { NS }\end{array}$ \\
\hline & & from 4 to $9 \mathrm{mo}(\mathrm{N}=30,30)$ & . & $\begin{array}{l}2013 \pm 100 \text { vs } 1925 \\
\pm 101 ; \text { NS }\end{array}$ \\
\hline & & Length gain (mean $\pm \mathrm{SE}, \mathrm{cm}$ ) & & \\
\hline & & from 4 to $6 \mathrm{mo}(\mathrm{N}=34,31)$ & . & $\begin{array}{l}3.02 \pm 0.15 \text { vs } 3.37 \\
\pm 0.16 ; \text { NS }\end{array}$ \\
\hline & & from 6 to $9 \mathrm{mo}(\mathrm{N}=30,30)$ & . & $\begin{array}{l}4.22 \pm 0.21 \text { vs } 4.00 \\
\pm 0.21 ; \mathrm{NS}\end{array}$ \\
\hline & & from 4 to $9 \mathrm{mo}(\mathrm{N}=30,30)$ & . & $\begin{array}{l}7.14 \pm 0.23 \text { vs } 7.31 \\
\pm 0.23 ; \mathrm{NS}\end{array}$ \\
\hline & & Change in head circumference (mean $\pm \mathrm{SE}, \mathrm{cm}$ ) & & \\
\hline & & from 4 to $6 \mathrm{mo}(\mathrm{N}=34,31)$ & . & $\begin{array}{l}1.74 \pm 0.06 \text { vs } 1.57 \\
\pm 0.06 ; \text { NS }\end{array}$ \\
\hline & & from 6 to $9 \mathrm{mo}(\mathrm{N}=30,30)$ & . & $\begin{array}{l}2.09 \pm 0.07 \text { vs } 2.00 \\
\pm 0.07 ; \mathrm{NS}\end{array}$ \\
\hline & & from 4 to $9 \mathrm{mo}(\mathrm{N}=30,30)$ & $\begin{array}{l}3.84 \pm 0.09 \text { vs } 3.56 \pm \\
0.09 ; p=0.03\end{array}$ & . \\
\hline
\end{tabular}

\section{Iron from supplement compared to iron from fortified food}




\section{Article}

Study design Iron from supplements intervention vs comparator ${ }^{\dagger}$

Growth, size, and body composition

outcome ${ }^{\ddagger}$

\section{Capozzi $2011^{2}$ \\ EBF 5-6 mo and weaned with iron-fortified food vs EBF PC or NRCT or RCT§ 5-6 mo (weaning CF NR) and given iron supplement from 4 to $9 \mathrm{mo}(1 \mathrm{mg} / \mathrm{kg} / \mathrm{d})$}

Italy

Weight (mean $\pm \mathrm{SD}, \mathrm{kg}$ )

In males $(\mathrm{N}=12,14)$

at $6 \mathrm{mo} \quad 7.3 \pm 0.8$ vs $7.2 \pm 0.8$;

$\mathrm{p}<0.05$

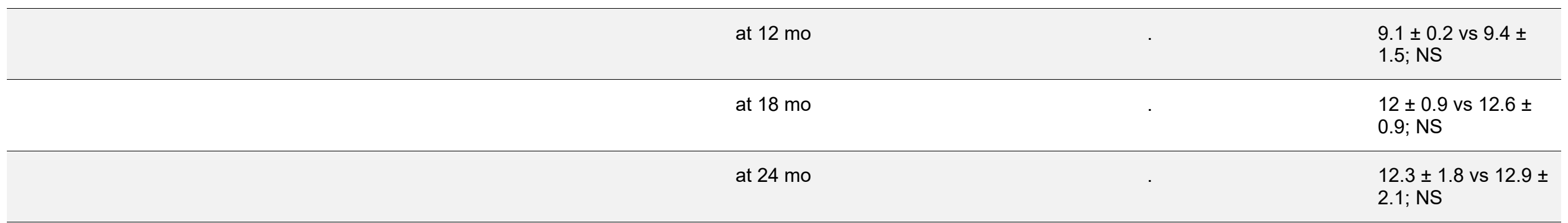

In females $(\mathrm{N}=16,12)$
at $6 \mathrm{mo}$
$7 \pm 0.6$ vs $7.2 \pm 0.9$

$\mathrm{p}<0.05$

\begin{tabular}{|c|c|c|}
\hline at $12 \mathrm{mo}$ & & $\begin{array}{l}9 \pm 1 \text { vs } 9.1 \pm 1.1 \\
\text { NS }\end{array}$ \\
\hline at $18 \mathrm{mo}$ & . & $\begin{array}{l}10.5 \pm 0.9 \text { vs } 11.9 \pm \\
1.8 ; \text { NS }\end{array}$ \\
\hline at $24 \mathrm{mo}$ & $\begin{array}{l}11.2 \pm 0.7 \text { vs } 12.8 \pm \\
1.1 ; p<0.05\end{array}$ & \\
\hline
\end{tabular}

Length (mean $\pm \mathrm{SD}, \mathrm{cm})$ at $6 \mathrm{mo}$

In males $(\mathrm{N}=12,14)$

at $6 \mathrm{mo}$

$67.1 \pm 0.3$ vs $67.1 \pm$

0.6 ; NS

at $12 \mathrm{mo}$

at $18 \mathrm{mo}$
$74.5 \pm 0.9$ vs $73.4 \pm$

$0.7 ; p<0.05$

$80.2 \pm 2.2$ vs $78.1 \pm$

$1.2 ; p<0.05$ 


\section{Article}

Study desig

Iron from supplements intervention vs comparator ${ }^{\dagger}$

Growth, size, and body composition

outcome $\ddagger$

In females $(\mathrm{N}=16,12)$

at $6 \mathrm{mo}$

at $12 \mathrm{mo}$

at $18 \mathrm{mo}$

at $24 \mathrm{mo}$

Iron-fortified FF and weaned at 5-6 mo with iron-fortified food vs EBF 5-6 mo (weaning CF NR) and given iron supplement from 4 to $9 \mathrm{mo}(1 \mathrm{mg} / \mathrm{kg} / \mathrm{d})$
In males $(\mathrm{N}=14,14)$
at $6 \mathrm{mo}$
$7.2 \pm 0.1$ vs $7.2 \pm 0.8$

$\mathrm{p}<0.05$

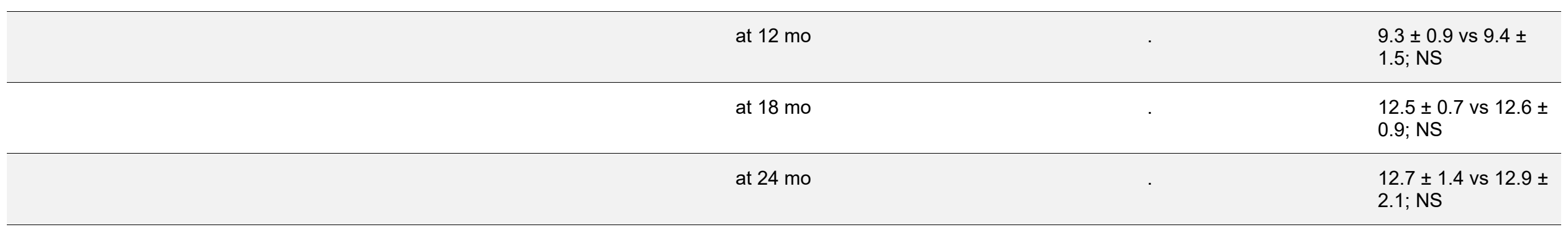

In females $(\mathrm{N}=18,12)$

$\begin{array}{ll}\text { at } 6 \mathrm{mo} & 7.1 \pm 0.9 \text { vs } 7.2 \pm 0.9 \text {; } \\ \mathrm{p}<0.05\end{array}$

at $12 \mathrm{mo}$

$9 \pm 0.8$ vs $9.1 \pm 1.1$

NS

at $18 \mathrm{mo}$

$11 \pm 0.7$ vs $11.9 \pm$

$1.8 ;$ NS 


\section{Article}

Study design Iron from supplements intervention vs comparator ${ }^{\dagger}$

Growth, size, and body composition

outcome ${ }^{\ddagger}$

Length (mean $\pm \mathrm{SD}, \mathrm{cm}$ ) at $6 \mathrm{mo}$

In males $(\mathrm{N}=14,14)$

at $6 \mathrm{mo}$

$67.2 \pm 1.5$ vs $67.1 \pm$

0.6 ; NS

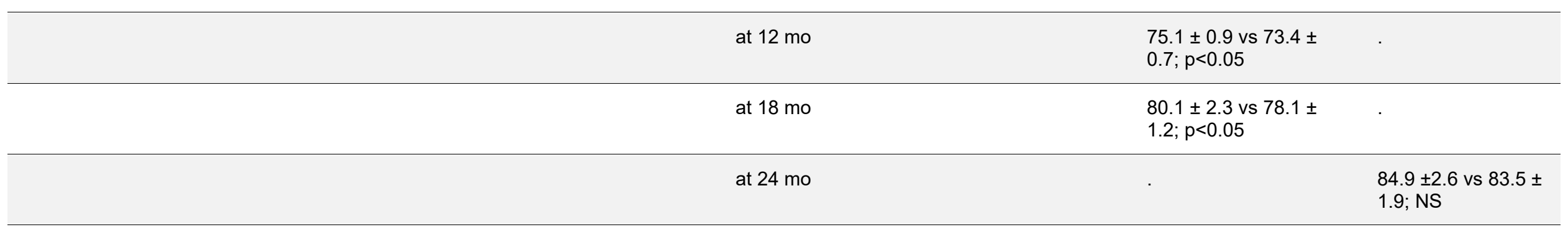

In females $(\mathrm{N}=18,12)$

at $6 \mathrm{mo}$

$64.3 \pm 1.6$ vs $63.9 \pm$

$1.3 ; \mathrm{NS}$

\begin{tabular}{|c|c|c|c|c|}
\hline & & at $12 \mathrm{mo}$ & $\begin{array}{l}71.9 \pm 1.6 \text { vs } 70 \pm 2.1 \\
p<0.05\end{array}$ & . \\
\hline & & at $18 \mathrm{mo}$ & $\begin{array}{l}78.1 \pm 1.6 \text { vs } 77.1 \pm \\
0.6 ; p<0.05\end{array}$ & \\
\hline & & at $24 \mathrm{mo}$ & . & $\begin{array}{l}82.6 \pm 1.6 \text { vs } 82.1 \pm \\
1.9 ; \mathrm{NS}\end{array}$ \\
\hline \multirow{3}{*}{$\begin{array}{l}\text { Szymley-Gay } \\
2016^{8} \\
\text { RCT } \\
\text { Sweden }\end{array}$} & $\begin{array}{l}\text { High-iron formula from } 6 \text { to } 7.5 \mathrm{mo}(6.6 \mathrm{mg} / \mathrm{d}) \text { vs No- } \\
\text { added-iron formula and iron supplement from } 6 \text { to } 7.5 \\
\mathrm{mo}(6.6 \mathrm{mg} / \mathrm{d})\end{array}$ & $\begin{array}{l}\text { Change in weight (mean }(95 \% \mathrm{Cl}), \mathrm{kg}) \text { from } 6 \text { to } \\
7.5 \mathrm{mo}(\mathrm{N}=23,20)\end{array}$ & . & $\begin{array}{l}0.0(-0.1,0.1) \\
p=0.956\end{array}$ \\
\hline & & Change in WAZ from 6 to $7.5 \mathrm{mo}(\mathrm{N}=23,20)$ & . & NS; data NR \\
\hline & & $\begin{array}{l}\text { Change in length (mean }(95 \% \mathrm{Cl}), \mathrm{cm}) \text { from } 6 \text { to } \\
7.5 \mathrm{mo}(\mathrm{N}=23,20)\end{array}$ & . & $\begin{array}{l}-0.3(-0.9,0.3) \\
p=0.369\end{array}$ \\
\hline
\end{tabular}




\begin{tabular}{|c|c|c|c|c|}
\hline $\begin{array}{l}\text { Article } \\
\text { Study design } \\
\text { Country }\end{array}$ & Iron from supplements intervention vs comparator ${ }^{\dagger}$ & $\begin{array}{l}\text { Growth, size, and body composition } \\
\text { outcome }^{\ddagger}\end{array}$ & Significant findings & $\begin{array}{l}\text { Nonsignificant } \\
\text { findings }\end{array}$ \\
\hline & & Change in LAZ from 6 to $7.5 \mathrm{mo}(\mathrm{N}=23,20)$ & & NS; data NR \\
\hline & & $\begin{array}{l}\text { Change in head circumference (mean }(95 \% \mathrm{Cl}) \text {, } \\
\mathrm{cm}) \text { from } 6 \text { to } 7.5 \text { mo }(\mathrm{N}=23,20)\end{array}$ & $-0.2(-0.4,0.0) ; p=0.046$ & \\
\hline & & Change in HCAZ from 6 to $7.5 \mathrm{mo}(\mathrm{N}=23,20)$ & . & NS; data NR \\
\hline & & $\begin{array}{l}\text { Change in knee-heel length (mean }(95 \% \mathrm{Cl}) \text {, } \\
\mathrm{mm}) \text { from } 6 \text { to } 7.5 \mathrm{mo}(\mathrm{N}=23,20)\end{array}$ & . & $\begin{array}{l}-0.4(-2.7,1.9) \\
p=0.751\end{array}$ \\
\hline & $\begin{array}{l}\text { No-added-iron formula and iron supplement from } 6 \text { to } 7.5 \\
\mathrm{mo}(6.6 \mathrm{mg} / \mathrm{d}) \text { vs Low-iron formula from } 6 \text { to } 7.5 \mathrm{mo}(1.3 \\
\mathrm{mg} / \mathrm{d})\end{array}$ & $\begin{array}{l}\text { Change in weight (mean }(95 \% \mathrm{Cl}), \mathrm{kg}) \text { from } 6 \text { to } \\
7.5 \mathrm{mo}(\mathrm{N}=23,20)\end{array}$ & . & $\begin{array}{l}0.0(-0.2,0.1) \\
p=0.696\end{array}$ \\
\hline & & Change in WAZ from 6 to $7.5 \mathrm{mo}(\mathrm{N}=23,20)$ & . & NS; data NR \\
\hline & & $\begin{array}{l}\text { Change in length (mean }(95 \% \mathrm{Cl}), \mathrm{cm}) \text { from } 6 \text { to } \\
7.5 \mathrm{mo}(\mathrm{N}=23,20)\end{array}$ & . & $\begin{array}{l}0.0(-0.6,0.6) \\
p=0.991\end{array}$ \\
\hline & & Change in LAZ from 6 to $7.5 \mathrm{mo}(\mathrm{N}=23,20)$ & . & NS; data NR \\
\hline & & $\begin{array}{l}\text { Change in head circumference (mean }(95 \% \mathrm{Cl}) \text {, } \\
\mathrm{cm}) \text { from } 6 \text { to } 7.5 \mathrm{mo}(\mathrm{N}=22,20)\end{array}$ & . & $\begin{array}{l}0.0(-0.2,0.1) \\
p=0.709\end{array}$ \\
\hline & & Change in HCAZ from 6 to $7.5 \mathrm{mo}(\mathrm{N}=22,20)$ & . & NS; data NR \\
\hline & & $\begin{array}{l}\text { Change in knee-heel length (mean }(95 \% \mathrm{Cl}) \text {, } \\
\mathrm{mm}) \text { from } 6 \text { to } 7.5 \mathrm{mo}(\mathrm{N}=23,20)\end{array}$ & . & $\begin{array}{l}-0.6(-2.9,1.8) \\
p=0.632\end{array}$ \\
\hline \multirow[t]{4}{*}{$\begin{array}{l}\text { Ziegler } 2009^{9} \\
\text { RCT } \\
\text { US }\end{array}$} & $\begin{array}{l}\text { Iron supplement from } 4 \text { to } 9 \mathrm{mo}(7.5 \mathrm{mg} / \mathrm{d}) \text { vs iron from } \\
\text { iron-fortified cereal from } 4 \text { to } 9 \mathrm{mo}(\sim 7 \mathrm{mg} / \mathrm{d})\end{array}$ & $\begin{array}{l}\text { Weight (mean } \pm S D, g) \text { at } 9 \text { mo } \\
\text { In male subsample }(\mathrm{N}=18,19)\end{array}$ & . & $\begin{array}{l}9114 \pm 970 \text { vs } 8883 \\
\pm 755 ; \text { NS }\end{array}$ \\
\hline & & In female subsample $(\mathrm{N}=23,19)$ & . & $\begin{array}{l}8197 \pm 732 \text { vs } 8496 \\
\pm 871 ; \text { NS }\end{array}$ \\
\hline & & $\begin{array}{l}\text { Weight gain (mean } \pm S D, g / d) \text { from } 4 \text { to } 9 \text { mo } \\
(N=41,38)\end{array}$ & . & $\begin{array}{l}12.18 \text { (SD NR) vs } \\
13.13 \text { (SD NR); NS }\end{array}$ \\
\hline & & In male subsample $(\mathrm{N}=18,19)$ & . & $\begin{array}{l}12.7 \pm 2.39 \text { vs } 13.0 \\
\pm 2.57 ; \mathrm{NS}\end{array}$ \\
\hline
\end{tabular}




\section{Article}

Study design

Iron from supplements intervention vs comparator ${ }^{\dagger}$

Growth, size, and body composition

outcome ${ }^{\ddagger}$

Significant findings

Nonsignificant

Country

In female subsample $(\mathrm{N}=23,19)$

$11.6 \pm 3.23$ vs 13.2

\pm 2.73 ; NS

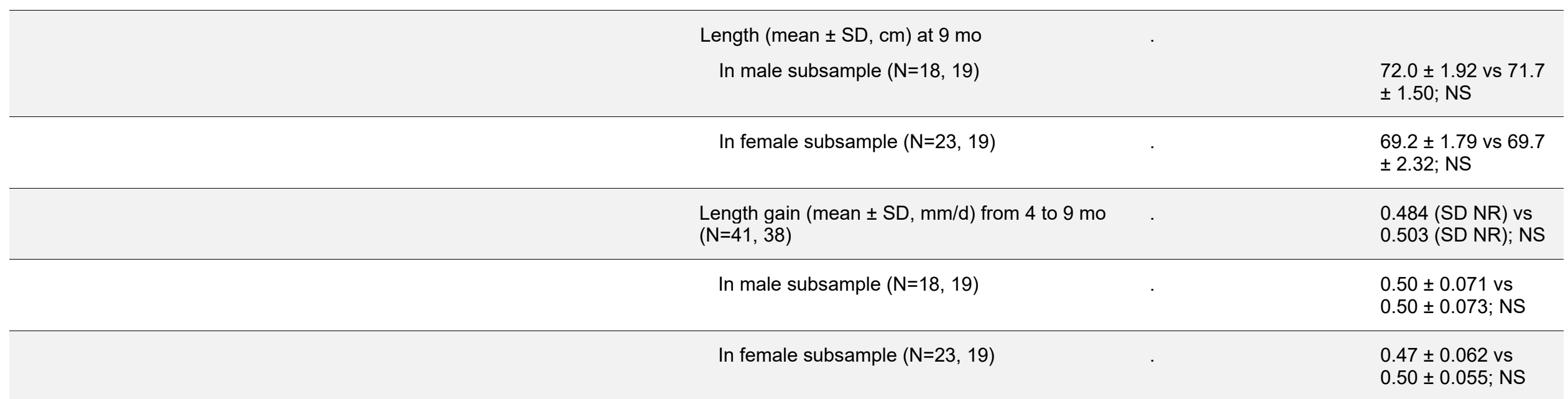

*Abbreviations: BMlz - body mass index Z score, $\mathrm{Cl}$ - confidence interval, $\mathrm{CF}$ - complementary foods, EBF - exclusively breastfed, $\mathrm{FF}$ - formula fed, HAZ - height-for-age Z score, HCAZ - head circumference-for-age $Z$ score, LAZ - length-for-age Z score, NR - not reported, NRCT - non randomized controlled trial, PC - prospective cohort, RCTrandomized controlled trial, SD -standard deviation, SE - standard error, WAZ - weight-for-age Z score, WHZ - weight-for-height Z score, WLZ - weight-for-length Z score

$\dagger$ Interventions and comparators, from the articles included in the body of evidence, which compare iron from supplements with a control, a placebo, a different level of iron from supplements, or iron from fortified foods

$\ddagger$ Outcomes, from the articles included in the body of evidence, which address growth, size, or body composition

$\S$ Authors did not clearly describe the study design; we cannot tell whether and to which groups infants were randomly allocated 
Table 4. Risk of bias for randomized controlled trials examining iron from supplements consumed during infancy and toddlerhood and growth, size, and body composition ${ }^{*}$

\begin{tabular}{|c|c|c|c|c|c|c|}
\hline & Randomization & $\begin{array}{c}\text { Identification of } \\
\text { participants - } \\
\text { randomization } \\
\end{array}$ & $\begin{array}{c}\text { Deviations from } \\
\text { intended } \\
\text { interventions }\end{array}$ & $\begin{array}{c}\text { Missing } \\
\text { outcome data }\end{array}$ & $\begin{array}{c}\text { Outcome } \\
\text { measurement }\end{array}$ & $\begin{array}{l}\text { Selection of the } \\
\text { reported result }\end{array}$ \\
\hline da Silva, $2008^{3}$ & Some Concerns & Low & $\begin{array}{c}\text { Some } \\
\text { Concerns }\end{array}$ & $\begin{array}{c}\text { Some } \\
\text { Concerns }\end{array}$ & $\begin{array}{c}\text { Some } \\
\text { Concerns }\end{array}$ & Low \\
\hline Dewey, $2002^{4}$ & Low & Low & Low & Low & Low & Low \\
\hline Friel, $\mathbf{2 0 0 3}^{5}$ & Some Concerns & Low & $\begin{array}{c}\text { Some } \\
\text { Concerns }\end{array}$ & High & $\begin{array}{c}\text { Some } \\
\text { Concerns }\end{array}$ & Low \\
\hline Hacihamdioglu, $2013^{6}$ & High & Low & $\begin{array}{c}\text { Some } \\
\text { Concerns }\end{array}$ & $\begin{array}{c}\text { Some } \\
\text { Concerns }\end{array}$ & $\begin{array}{c}\text { Some } \\
\text { Concerns }\end{array}$ & Low \\
\hline Lozoff, $2016^{7}$ & High & Low & Low & $\begin{array}{c}\text { Some } \\
\text { Concerns }\end{array}$ & $\begin{array}{c}\text { Some } \\
\text { Concerns }\end{array}$ & Low \\
\hline Szymley-Gay, $2016^{8}$ & Low & Low & $\begin{array}{c}\text { Some } \\
\text { Concerns }\end{array}$ & $\begin{array}{c}\text { Some } \\
\text { Concerns }\end{array}$ & $\begin{array}{c}\text { Some } \\
\text { Concerns }\end{array}$ & Low \\
\hline Ziegler, $2009^{9}$ & $\begin{array}{c}\text { Some } \\
\text { Concerns }\end{array}$ & Low & $\begin{array}{c}\text { Some } \\
\text { Concerns }\end{array}$ & $\begin{array}{c}\text { Some } \\
\text { Concerns }\end{array}$ & $\begin{array}{c}\text { Some } \\
\text { Concerns }\end{array}$ & Low \\
\hline Ziegler, 200910 & High & Low & Low & $\begin{array}{c}\text { Some } \\
\text { Concerns }\end{array}$ & Low & Low \\
\hline
\end{tabular}

" A detailed description of the methodology used for assessing risk of bias is available on the NESR website: https://nesr.usda.gov/2020-dietary-guidelinesadvisory-committee-systematic-reviews and in Part C of the following reference: Dietary Guidelines Advisory Committee. 2020. Scientific Report of the 2020 Dietary Guidelines Advisory Committee: Advisory Report to the Secretary of Agriculture and the Secretary of Health and Human Services. U.S. Department of Agriculture, Agricultural Research Service, Washington, DC.

† Possible ratings of low, some concerns, or high determined using the "Cochrane Risk-of-bias 2.0" (RoB 2.0) (August 2016 version)" (Higgins JPT, Sterne JAC, Savović J, Page MJ, Hróbjartsson A, Boutron I, Reeves B, Eldridge S. A revised tool for assessing risk of bias in randomized trials In: Chandler J, McKenzie J, Boutron I, Welch V (editors). Cochrane Methods. Cochrane Database of Systematic Reviews 2016, Issue 10 (Suppl 1)

dx.doi.org/10.1002/14651858.CD201601.) 
Table 5. Risk of bias for the non-randomized controlled trial examining iron from supplements consumed during infancy and toddlerhood and growth, size, and body composition ${ }^{\star} \dagger$

\begin{tabular}{|c|c|c|c|c|c|c|c|}
\hline & Confounding & $\begin{array}{l}\text { Selection of } \\
\text { participants }\end{array}$ & $\begin{array}{l}\text { Classification } \\
\text { of interventions }\end{array}$ & $\begin{array}{l}\text { Deviations } \\
\text { from intended } \\
\text { interventions }\end{array}$ & Missing data & $\begin{array}{c}\text { Outcome } \\
\text { measurement }\end{array}$ & $\begin{array}{l}\text { Selection of the } \\
\text { reported result }\end{array}$ \\
\hline Azeredo $2010^{1}$ & Serious & Serious & Low & Low & Serious & Low & Low \\
\hline
\end{tabular}

* A detailed description of the methodology used for assessing risk of bias is available on the NESR website: https://nesr.usda.gov/2020-dietary-guidelinesadvisory-committee-systematic-reviews and in Part C of the following reference: Dietary Guidelines Advisory Committee. 2020. Scientific Report of the 2020 Dietary Guidelines Advisory Committee: Advisory Report to the Secretary of Agriculture and the Secretary of Health and Human Services. U.S. Department of Agriculture, Agricultural Research Service, Washington, DC.

${ }^{\dagger}$ Possible ratings of low, moderate, serious, critical, or no information determined using the "Risk of Bias in Non-randomized Studies of Interventions (ROBINS-I) tool" (Sterne JAC, Hernán MA, Reeves BC, Savović J, Berkman ND, Viswanathan M, Henry D, Altman DG, Ansari MT, Boutron I, Carpenter JR, Chan AW, Churchill R, Deeks JJ, Hróbjartsson A, Kirkham J, Jüni P, Loke YK, Pigott TD, Ramsay CR, Regidor D, Rothstein HR, Sandhu L, Santaguida PL, Schünemann HJ, Shea B, Shrier I, Tugwell P, Turner L, Valentine JC, Waddington H, Waters E, Wells GA, Whiting PF, Higgins JPT. ROBINS-I: a tool for assessing risk of bias in non-randomized studies of interventions. BMJ 2016; 355; i4919; doi: 10.1136/bmj.i4919.) 
Table 6. Risk of bias for the observational study examining iron from supplements consumed during infancy and toddlerhood and growth, size, and body composition ${ }^{*}$

\begin{tabular}{|c|c|c|c|c|c|c|c|}
\hline & Confounding & $\begin{array}{l}\text { Selection of } \\
\text { participants }\end{array}$ & $\begin{array}{l}\text { Classification } \\
\text { of exposures }\end{array}$ & $\begin{array}{l}\text { Deviations } \\
\text { from intended } \\
\text { exposures }\end{array}$ & Missing data & $\begin{array}{c}\text { Outcome } \\
\text { measurement }\end{array}$ & $\begin{array}{l}\text { Selection of the } \\
\text { reported result }\end{array}$ \\
\hline Capozzi 2011 & Serious & No information & Critical & Moderate & No information & Moderate & Serious \\
\hline
\end{tabular}

*A detailed description of the methodology used for assessing risk of bias is available on the NESR website: https://nesr.usda.gov/2020-dietary-guidelinesadvisory-committee-systematic-reviews and in Part C of the following reference: Dietary Guidelines Advisory Committee. 2020. Scientific Report of the 2020 Dietary Guidelines Advisory Committee: Advisory Report to the Secretary of Agriculture and the Secretary of Health and Human Services. U.S. Department of Agriculture, Agricultural Research Service, Washington, DC

† Possible ratings of low, moderate, serious, critical, or no information determined using the "Risk of Bias for Nutrition Observational Studies" tool (RoB-NObs) (Dietary Guidelines Advisory Committee. 2020. Scientific Report of the 2020 Dietary Guidelines Advisory Committee: Advisory Report to the Secretary of Agriculture and the Secretary of Health and Human Services. U.S. Department of Agriculture, Agricultural Research Service, Washington, DC.)

‡ Insufficient reporting made it difficult to determine whether this study was a randomized controlled trial, non-randomized controlled trial, or prospective cohort study; we have assessed its risk of bias as a prospective cohort study 


\section{Research recommendations}

- Evaluate how to best identify and treat infants who become iron deficient before 6 months of age, including populations with racial and ethnic diversity.

- Investigate the biological mechanisms by which iron supplementation during infancy may affect growth, including potential effects on morbidity, the microbiome, zinc status, and oxidative stress or lipid peroxidation.

\section{Included articles}

1. Azeredo CM, Cotta RM, Sant'Ana LF, et al. Greater effectiveness of daily iron supplementation scheme in infants. Rev Saude Publica. 2010;44(2):230-239.doi: 10.1590/s003489102010000200002.

2. Capozzi L, Russo R, Bertocco F, Ferrara D, Ferrara M. Effect on haematological and anthropometric parameters of iron supplementation in the first 2 years of life. Risks and benefits. Hematology. 2011;16(5):261-264.doi: 10.1179/102453311X13085644679980.

3. da Silva G, Franceschini Sdo C, Sigulem DM. Growth in non-anemic infants supplemented with different prophylactic iron doses. J Pediatr (Rio J). 2008;84(4):365-372.doi: 10.2223/JPED.1817.

4. Dewey KG, Domellof M, Cohen RJ, Landa Rivera L, Hernell O, Lonnerdal B. Iron supplementation affects growth and morbidity of breast-fed infants: results of a randomized trial in Sweden and Honduras. J Nutr. 2002;132(11):3249-3255.doi: 10.1093/jn/132.11.3249.

5. Friel JK, Aziz K, Andrews WL, Harding SV, Courage ML, Adams RJ. A double-masked, randomized control trial of iron supplementation in early infancy in healthy term breast-fed infants. J Pediatr. 2003;143(5):582-586.doi: 10.1067/S0022-3476(03)00301-9.

6. Hacihamdioglu DO, Kurekci AE, Gursel O, et al. Evaluation of lipid peroxidation and antioxidant system in healthy iron-replete infants receiving iron prophylaxis. Nutrition. 2013;29(1):138142.doi: 10.1016/j.nut.2012.05.009.

7. Lozoff B, Jiang Y, Li X, et al. Low-Dose Iron Supplementation in Infancy Modestly Increases Infant Iron Status at 9 Mo without Decreasing Growth or Increasing Illness in a Randomized Clinical Trial in Rural China. J Nutr. 2016;146(3):612-621.doi: 10.3945/jn.115.223917.

8. Szymlek-Gay EA, Domellof M, Hernell O, et al. Mode of oral iron administration and the amount of iron habitually consumed do not affect iron absorption, systemic iron utilisation or zinc absorption in iron-sufficient infants: a randomised trial. Br J Nutr. 2016;116(6):1046-1060.doi: 10.1017/S0007114516003032.

9. Ziegler EE, Nelson SE, Jeter JM. Iron status of breastfed infants is improved equally by medicinal iron and iron-fortified cereal. Am J Clin Nutr. 2009;90(1):76-87.doi: 10.3945/ajcn.2008.27350.

10.Ziegler EE, Nelson SE, Jeter JM. Iron supplementation of breastfed infants from an early age. Am J Clin Nutr. 2009;89(2):525-532.doi: 10.3945/ajcn.2008.26591. 


\section{METHODOLOGY}

The NESR team used its rigorous, protocol-driven methodology to support the 2020 Dietary Guidelines Advisory Committee in conducting this systematic review.

NESR's systematic review methodology involves:

- Developing a protocol,

- Searching for and selecting studies,

- Extracting data from and assessing the risk of bias of each included study,

- Synthesizing the evidence,

- Developing conclusion statements,

- Grading the evidence underlying the conclusion statement, and

- Recommending future research.

A detailed description of the methodology used in conducting this systematic review is available on the NESR website: https://nesr.usda.gov/2020-dietary-guidelines-advisory-committee-systematicreviews, and can be found in the 2020 Dietary Guidelines Advisory Committee Report, Part C: Methodology. ${ }^{\vee}$ This systematic review was peer reviewed by Federal scientists, and information about the peer review process can also be found in the Committee's Report, Part C. Methodology. Additional information about this systematic review, including a description of and rationale for any modifications made to the protocol can be found in the 2020 Dietary Guidelines Advisory Committee Report, Chapter 6. Nutrients from Dietary Supplements During Infancy and Toddlerhood.

Below are details of the final protocol for the systematic review described herein, including the:

- Analytic framework

- Literature search and screening plan

- Literature search and screening results

` Dietary Guidelines Advisory Committee. 2020. Scientific Report of the 2020 Dietary Guidelines Advisory Committee: Advisory Report to the Secretary of Agriculture and the Secretary of Health and Human Services. U.S. Department of Agriculture, Agricultural Research Service, Washington, DC. 


\section{ANALYTIC FRAMEWORK}

The analytic framework (Figure 1) illustrates the overall scope of the systematic review, including the population, the interventions and/or exposures, comparators, and outcomes of interest. It also includes definitions of key terms and identifies key confounders and other factors considered in the systematic review. The inclusion and exclusion criteria that follow provide additional information about how parts of the analytic framework were defined and operationalized for the review.

\section{Figure 1: Analytic framework}

\section{Systematic review question: What is the relationship between iron from supplements consumed during infancy} and toddlerhood and growth, size, and body composition?

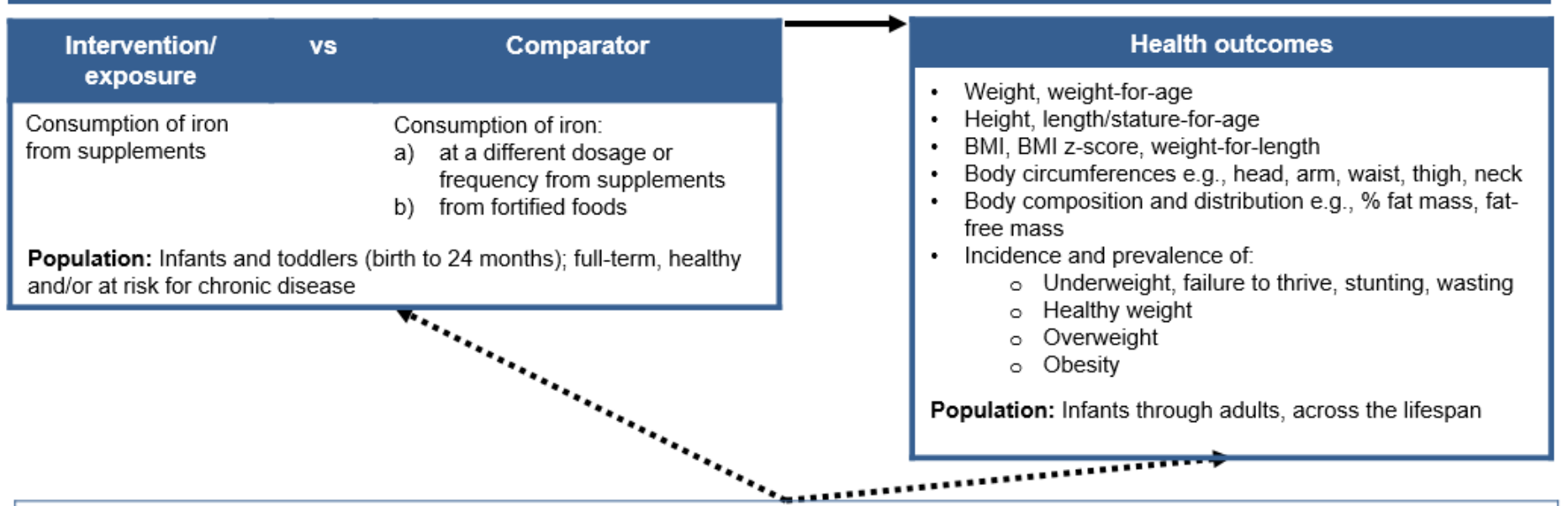

Key Confounders: Gestational age, Sex, Race/ethnicity, Socioeconomic status, Parental education, Feeding practices (e.g., human milk/infant formula history), Use of foods that are fortified or rich in the nutrient of interest (in supplements studies), Anthropometry at birth or baseline

Other factors to be considered: Maternal age, Prenatal vitamin-supplement use, Timing of cord-clamping, Smoking, Maternal Anthropometry

\section{Key definitions}

- Dietary Supplement- a product (other than tobacco) that: is intended to supplement the diet; contains one or more dietary ingredients (including vitamins; minerals; herbs or other botanicals; amino acids; and other substances) or their constituents; is intended to be taken by mouth as a pill, capsule, tablet, or liquid; and is labeled on the front panel as being a dietary supplement. (ODS, Dietary Supplement Health and Education Act, 1994)

- Fortification - as defined by the U.S. Food and Drug Administration (FDA), the deliberate addition of one or more essential nutrients to a food, whether or not it is normally contained in the food. Fortification may be used to prevent or correct a demonstrated deficiency in the population or specific population groups; restore naturally occurring nutrients lost during processing, storage, or handling; or to add a nutrient to a food at the level found in a comparable traditional food. When cereal grains are labeled as enriched, it is mandatory that they be fortified with folic acid
Legend

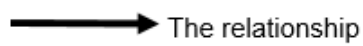
of interest in the systematic review

Factors that may impact the relationship of interest in the systematic review 


\section{LITERATURE SEARCH AND SCREENING PLAN}

\section{Inclusion and exclusion criteria}

This table provides the inclusion and exclusion criteria for the systematic review. The inclusion and exclusion criteria are a set of characteristics that were used to determine which articles identified in the literature search were included in or excluded from the systematic review.

Table 7. Inclusion and exclusion criteria

\begin{tabular}{|c|c|c|}
\hline Category & Inclusion Criteria & Exclusion Criteria \\
\hline $\begin{array}{l}\text { Study } \\
\text { design }\end{array}$ & $\begin{array}{l}\text { - } \text { Randomized controlled trials } \\
\text { - Non-randomized controlled trials, } \\
\text { including quasi-experimental and } \\
\text { controlled before and after studies } \\
\text { - } \text { Prospective cohort studies } \\
\text { - } \quad \text { Retrospective cohort studies } \\
\text { - } \quad \text { Nested case-control studies }\end{array}$ & $\begin{array}{l}\text { - Uncontrolled trials } \\
\text { - Case-control studies } \\
\text { - Cross-sectional studies } \\
\text { - Uncontrolled before-and-after } \\
\text { - } \text { studies } \\
\text { - Sarrative reviews } \\
\text { - } \text { Systematic reviews } \\
\text { - Meta-analyses }\end{array}$ \\
\hline $\begin{array}{l}\text { Intervention/ } \\
\text { exposure }\end{array}$ & $\begin{array}{l}\text { - Studies that examine consumption } \\
\text { of iron from supplements } \\
\text { - Studies that specify the } \\
\text { dosage/amount of iron received }\end{array}$ & $\begin{array}{l}\text { - Studies that do not specify } \\
\text { the dosage/amount of iron } \\
\text { received } \\
\text { - Studies that vary nutrients } \\
\text { other than iron without } \\
\text { controlling for that variation }\end{array}$ \\
\hline Comparator & $\begin{array}{l}\text { - Studies that compare consumption } \\
\text { of iron: } \\
\circ \text { at a different dosage or } \\
\text { frequency from supplements } \\
\circ \text { from fortified foods }\end{array}$ & - $\quad N / A$ \\
\hline
\end{tabular}




\begin{tabular}{|c|c|}
\hline Cate & clusic \\
\hline Outcomes & $\begin{array}{l}\text { - Weight, weight-for-age } \\
\text { - Length or height, length/stature- } \\
\text { for-age } \\
\text { - BMI, BMI z-score, weight-for- } \\
\text { length } \\
\text { - Body circumferences e.g., head, } \\
\text { arm, waist, thigh, neck } \\
\text { - Body composition and distribution } \\
\text { e.g., \% fat mass, fat-free mass, } \\
\text { skinfold thickness } \\
\text { - Incidence and prevalence of: } \\
\circ \text { Underweight, failure to thrive, } \\
\text { stunting, wasting } \\
\circ \text { Healthy weight } \\
\circ \text { Rapid infant weight gain } \\
\circ \text { Overweight } \\
\circ \text { Obesity }\end{array}$ \\
\hline
\end{tabular}

\begin{tabular}{|c|c|}
\hline $\begin{array}{l}\text { Date of } \\
\text { publication }\end{array}$ & - January 2000 - January 2020 \\
\hline
\end{tabular}

$\begin{array}{lll}\begin{array}{l}\text { Publication } \\ \text { status }\end{array} & \begin{array}{l}\text { Articles that have been peer- } \\ \text { reviewed }\end{array}\end{array}$




\begin{tabular}{|c|c|c|}
\hline Category & Inclusion Criteria & Exclusion Criteria \\
\hline $\begin{array}{l}\text { Study } \\
\text { participants }\end{array}$ & $\begin{array}{l}\text { - Human participants } \\
\text { - Males } \\
\text { - Females }\end{array}$ & $\begin{array}{l}\text { - Non-human participants (e.g., } \\
\text { animal studies) }\end{array}$ \\
\hline $\begin{array}{l}\text { Age of } \\
\text { study } \\
\text { participants }\end{array}$ & 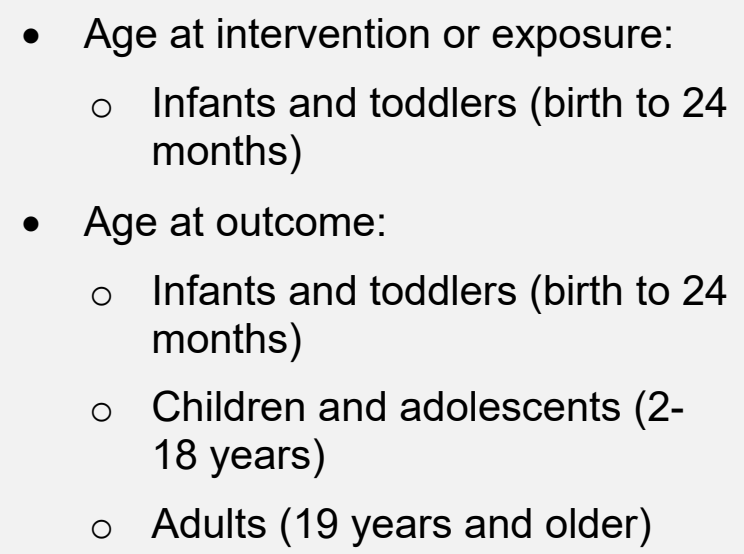 & $\begin{array}{l}\text { - Age at intervention or } \\
\text { exposure: } \\
\circ \text { Children and adolescents } \\
\text { (2-18 years) } \\
\circ \text { Adults (19 years and } \\
\text { older) }\end{array}$ \\
\hline $\begin{array}{l}\text { Health } \\
\text { status of } \\
\text { study } \\
\text { participants }\end{array}$ & $\begin{array}{l}\text { - Studies that enroll participants who } \\
\text { are healthy and/or at risk for } \\
\text { chronic disease } \\
\text { - Studies that enroll some } \\
\text { participants diagnosed with a } \\
\text { disease } \\
\text { - Studies that enroll some } \\
\text { participants classified as } \\
\text { underweight, stunted, wasted, or } \\
\text { obese. } \\
\text { - Studies that enroll infants born full- } \\
\text { term ( } \geq 37 \text { weeks and } 0 / 7 \text { days } \\
\text { gestational age) }\end{array}$ & $\begin{array}{l}\text { - Studies that exclusively } \\
\text { enroll participants diagnosed } \\
\text { with a disease. } \\
\text { - Studies that exclusively } \\
\text { enroll participants classified } \\
\text { as underweight, stunted, } \\
\text { wasted, or obese (i.e., studies } \\
\text { that aim to treat participants } \\
\text { who have already been } \\
\text { diagnosed with the outcome } \\
\text { of interest) } \\
\text { - Studies that exclusively } \\
\text { enroll infants born preterm } \\
\text { (gestational age }<37 \text { weeks } \\
\text { and } 0 / 7 \text { days), infants with } \\
\text { low birth weight }(<2500 g) \text {, } \\
\text { and/or infants born small for } \\
\text { gestational age }\end{array}$ \\
\hline
\end{tabular}

collected, the HDI classification for the year of publication was applied. HDI values are available from 1980, and then from 1990 to present. If a study was conducted prior to 1990, the HDI classification from 1990 was applied. If a study was conducted in 2018 or 2019, the most current HDI classification was applied. When a country was not included in the HDI ranking, the current country classification from the World Bank was used instead (The World Bank. World Bank country and lending groups. Available from:

https://datahelpdesk.worldbank.org/knowledgebase/articles/906519-world- country-and-lending-groups). 


\begin{tabular}{|c|c|c|}
\hline Category & Inclusion Criteria & Exclusion Criteria \\
\hline $\begin{array}{l}\text { Source of } \\
\text { Foods, } \\
\text { Beverages, } \\
\text { or Nutrients }\end{array}$ & 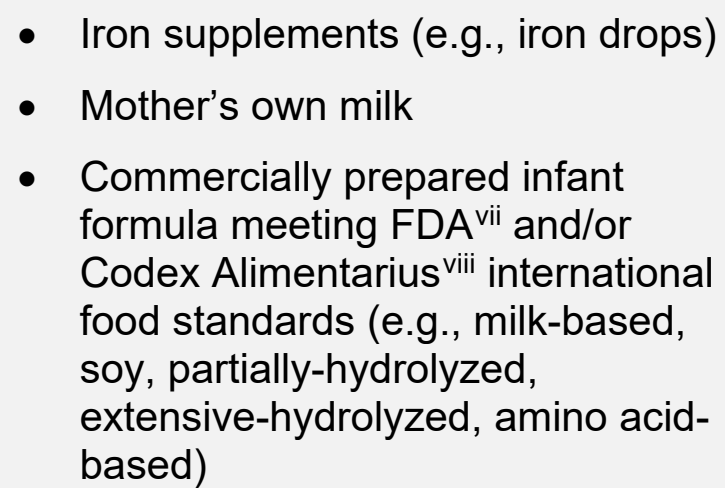 & $\begin{array}{l}\text { - Donor or banked milk } \\
\text { - Infant formulas that do not } \\
\text { meet FDA and/or Codex } \\
\text { Alimentarius standards }\end{array}$ \\
\hline
\end{tabular}

\section{Electronic databases and search terms}

\section{PubMed}

- Provider: U.S. National Library of Medicine

- Date(s) Searched: January 6, 2020

- Date range searched: January 1, 2000 - January 6, 2020

- Search terms:

\#1 - iron[Mesh] OR iron compounds[Mesh] OR iron[tiab] OR ferrous[tiab] OR ferric[tiab]

\#2 - Body Weights and Measures[Mesh] OR body weight[mh] OR obesity[tiab] OR obese[tiab] OR overweight[tiab] OR body mass index[tiab] OR BMI[tiab] OR underweight[tiab] OR wasting[tiab] OR healthy weight[tiab] OR Body Composition[Mesh] OR body composition[tiab] OR body fat[tiab] OR fat mass[tiab] OR fat free mass[tiab] OR stunting[tiab] OR stunted[tiab] OR growth charts[mh] OR growth chart*[tiab] OR Growth[Mesh:noexp] OR waist circumference[tiab] OR head circumference[tiab] OR arm circumference[tiab] OR thigh circumference[tiab] OR neck circumference[tiab] OR Anthropometry[Mesh:noexp] OR Overnutrition[Mesh] OR failure to thrive[Mesh] OR anthropometr*[tiab] OR adiposity[tiab] OR calf circumference[tiab] OR failure to thrive[tiab] OR skin fold*[tiab] OR healthy weight[tiab] OR weight for height[tiab] OR stature for age[tiab] OR weight for age[tiab] OR height for age[tiab] OR recumbent length[tiab] OR length for age[tiab] OR weight for length[tiab] OR rapid infant weight gain[tiab]

\#3 - dietary supplements[Mesh] OR supplement*[tiab] OR drops[tiab] OR multivitamin*[tiab]

\#4 - \#1 AND \#2 AND \#3

\footnotetext{
vii U.S. Food and Drug Administration. Version 19 December 2013. Internet: https://www.fda.gov/Food/GuidanceRegulation/GuidanceDocumentsRegulatoryInformation/InfantFormula/ucm13611 8.htm\#manufacture (accessed March 23, 2018).

viii Food and Agriculture Organization of the United Nations. World Health Organization. Codex Alimentarius. International Food Standards. Standard for infant formula and formulas for special medical purposes intended for infants. Codex Stan 72-1981. 2007.
} 
\#5 - \#4 NOT ("Animals"[Mesh] NOT ("Animals"[Mesh] AND "Humans"[Mesh]))

\#6 - \#4 NOT (editorial[ptyp] OR comment[ptyp] OR news[ptyp] OR letter[ptyp] OR review[ptyp] OR systematic review[ptyp] OR systematic review[ti] OR meta-analysis[ptyp] OR metaanalysis[ti] OR meta-analyses[ti] OR retracted publication[ptyp] OR retraction of publication[ptyp] OR retraction of publication[tiab] OR retraction notice[ti])

Filters: Publication date from 2000/01/01 to 2020/01/06; English

\section{Cochrane Central Register of Controlled Trials (CENTRAL)}

- Provider: John Wiley \& Sons

- Date(s) Searched: January 6, 2020

- Date range searched: January 1, 2000- January 6, 2020

- Search terms:

\#1 - [mh "iron"] OR [mh "iron compounds] OR iron OR ferrous OR ferric \#2 - [mh "Body Weights and Measures"] OR [mh "Body Weight"] OR obesity OR obese OR overweight OR "body mass index" OR BMI OR underweight OR wasting OR "healthy weight" OR [mh "Body Composition"] OR "body composition" OR "body fat" OR "fat mass" OR "fat free mass" OR stunting OR stunted OR [mh "Growth Charts"] OR "growth chart"” OR "waist circumference" OR "head circumference" OR "arm circumference" OR "thigh circumference" OR "neck circumference" OR [mh ^"Anthropometry"] OR [mh ^ "Growth"] OR [mh "Overnutrition"] OR [mh "failure to thrive"] OR anthropometr* OR adiposity OR "calf circumference" OR "failure to thrive" OR "skin fold" OR "skin fold"” OR "normal weight" OR "healthy weight" OR "weight for height" OR "stature for age" OR "weight for age" OR "height for age" OR "recumbent length" OR "length for age" OR "weight for length" OR "rapid infant weight gain"

\#3 - [mh "dietary supplement"] OR supplement* OR drops OR multivitamin*

\#4 - \#1 AND \#2 AND \#3

Filters: Publication Year from 2000 to 2020, Trials 


\section{Embase}

- Provider: Elsevier

- Date(s) Searched: January 6, 2020

- Date range searched: January 1, 2000 - January 6, 2020

- Search terms:

\#1 - 'iron'/exp OR 'iron derivative'/exp OR ferrous:ti, ab OR ferric:ti, ab OR OR iron:ti, ab

\#2 - 'morphometry'/exp OR obesity:ti,ab OR obese:ti,ab OR overweight:ti,ab OR 'body mass index':ti,ab OR bmi:ti,ab OR underweight:ti,ab OR wasting:ti,ab OR 'healthy weight':ti,ab OR 'body composition':ti,ab OR 'body fat':ti,ab OR 'fat mass':ti,ab OR 'fat free mass':ti,ab OR stunting:ti,ab OR stunted:ti,ab OR 'growth chart*':ti,ab OR 'waist circumference':ti,ab OR 'head circumference':ti,ab OR 'arm circumference':ti,ab OR 'thigh circumference':ti,ab OR 'neck circumference':ti,ab OR anthropometr*:ti,ab OR adiposity:ti,ab OR 'calf circumference':ti,ab OR 'failure to thrive':ti, ab OR 'skin fold*':ti,ab OR skinfold*:ti,ab OR 'normal weight':ti,ab OR 'weight for age':ti,ab OR 'height for age':ti,ab OR 'recumbent length':ti,ab OR 'length for age':ti,ab OR 'weight for length':ti,ab OR 'body composition'/mj OR 'waist circumference'/de OR 'body height'/de OR 'growth chart'/de OR 'body weight'/de OR 'anthropometry'/exp OR 'body growth'/de OR 'growth'/de OR 'overnutrition'/de OR 'failure to thrive'/exp OR 'weight for age'/exp OR 'height for age'/exp OR 'length for age'/exp OR 'rapid infant weight gain':ti,ab

\#3 - 'dietary supplement'/exp OR supplement*:ti,ab OR drops:ti,ab OR multivitamin*:ti,ab OR 'multivitamin'/exp

\#4 - \#1 AND \#2 AND \#3

\#5 - \#4 AND ([article]/lim OR [article in press]/lim) AND [humans]/lim AND [english]/lim AND [2000-2020]/py NOT ([conference abstract]/lim OR [conference paper]/lim OR [editorial]/lim OR [erratum]/lim OR [letter]/lim OR [note]/lim OR [review]/lim OR [systematic review]/lim OR [meta analysis]/lim)

\section{Cumulative Index of Nursing and Allied Health Literature (CINAHL Plus)}

- Provider: EBSCOhost

- Date(s) Searched: January 6, 2020

- Date range searched: January 1, 2000- January 6, 2020

- Search terms:

\#1 - (MH "Iron") OR (MH "iron compounds) OR iron OR ferrous OR ferric

\#2 - (MH "body weights and measures") OR (MH "body weight") OR obesity OR obese OR overweight OR "body mass index" OR BMI OR underweight OR wasting OR "healthy weight" OR (MH "body composition") OR "body composition" OR "body fat" OR "fat mass" OR "fat free mass" OR stunting OR stunted OR (MH "growth charts") OR "growth chart"” OR "waist circumference" OR "head circumference" OR "arm circumference" OR "thigh circumference" OR "neck circumference" OR (MH "anthropometry") OR (MH "Growth") OR (MH "overnutrition") OR (MH "failure to thrive") OR anthropometr" OR adiposity OR "calf circumference" OR "failure to thrive" OR "skin fold*” OR "skin fold*” OR "normal weight" OR "healthy weight" OR "weight for height" OR "stature for age" OR "weight for age" OR "height for age" OR "recumbent length" OR "length for age" OR "weight for length" OR "rapid infant weight gain" 
\#3 - (MH "dietary supplements") OR supplement* OR drops OR multivitamin*

\#4 - \#1 AND \#2 AND \#3

\#5 - \#4 NOT (MH "Literature Review" OR MH "Meta Analysis" OR MH "Systematic Review" OR MH "News" OR MH "Retracted Publication" OR MH "Retraction of Publication )

Filters: Published Date: 20000101 to 20200106, English, Human

\section{LITERATURE SEARCH AND SCREENING RESULTS}

The flow chart (Figure 2) below illustrates the literature search and screening results for articles examining the systematic review question. The results of the electronic database searches, after removal of duplicates, were screened independently by two NESR analysts using a step-wise process by reviewing titles, abstracts, and full-texts to determine which articles met the inclusion criteria. Refer to Table $\mathbf{8}$ for the rationale for exclusion for each excluded full-text article. A manual search was done to find articles that were not identified when searching the electronic databases; all manually identified articles are also screened to determine whether they met criteria for inclusion. 
Figure 2: Flow chart of literature search and screening results

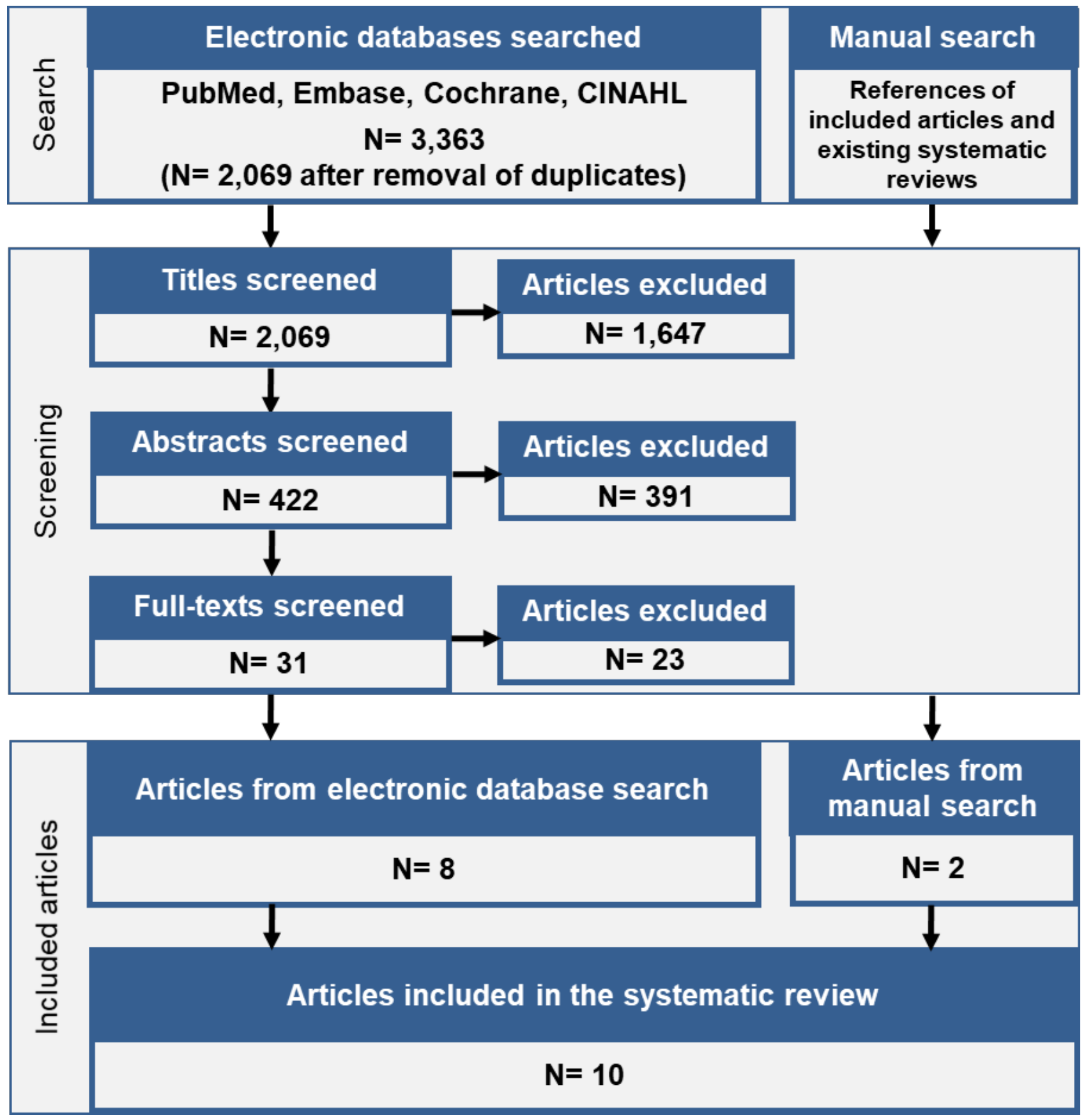




\section{Excluded articles}

The table below lists the articles excluded after full-text screening. At least one reason for exclusion is provided for each article, which may not reflect all possible reasons for exclusion. Information about articles excluded after title and abstract screening is available upon request.

\section{Table 8. Articles excluded after full text screening with rationale for exclusion}

\begin{tabular}{|c|c|c|}
\hline & Full texts screened & Rationale for exclusion \\
\hline 1 & $\begin{array}{l}\text { Abdelrazik, N.,Al-Haggar, M.,Al-Marsafawy, H.,Abdel-Hadi, H.,Al-Baz, R.,Mostafa, A. H. (2007). } \\
\text { Impact of long-term oral iron supplementation in breast-fed infants Indian J Pediatr, 74(8), 739-45 }\end{array}$ & $\begin{array}{l}\text { Intervention/exposure vs comparator, } \\
\text { Country }\end{array}$ \\
\hline 2 & $\begin{array}{l}\text { Allen, L. H.,Rosado, J. L.,Casterline, J. E.,Lopez, P.,Munoz, E.,Garcia, O. P.,Martinez, H. (2000). Lack } \\
\text { of hemoglobin response to iron supplementation in anemic mexican preschoolers with multiple } \\
\text { micronutrient deficiencies Am J Clin Nutr, 71(6), 1485-94 }\end{array}$ & Outcome, Participant age \\
\hline 3 & $\begin{array}{l}\text { Allen, L.,Shrimpton, R. (2005). The international research on infant supplementation study: } \\
\text { Implications for programs and further research Journal of Nutrition, 135(3), 666S-669S }\end{array}$ & Study design \\
\hline 4 & $\begin{array}{l}\text { Altucher, K.,Rasmussen, K. M.,Barden, E. M.,Habicht, J. (2005). Predictors of improvement in } \\
\text { hemoglobin concentration among toddlers enrolled in the Massachusetts WIC program Journal of the } \\
\text { American Dietetic Association, 105(5), 709-715 }\end{array}$ & Intervention/exposure vs comparator \\
\hline 5 & $\begin{array}{l}\text { Brown, K. H.,De Romaña, D. L.,Arsenault, J. E.,Peerson, J. M.,Penny, M. E. (2007). Comparison of } \\
\text { the effects of zinc delivered in a fortified food or a liquid supplement on the growth, morbidity, and } \\
\text { plasma zinc concentrations of young Peruvian children American Journal of Clinical Nutrition, 85(2), } \\
538-547\end{array}$ & Intervention/exposure vs comparator \\
\hline 6 & $\begin{array}{l}\text { Cotta, R. M. M.,Azeredo, C. M.,da Silva, L. S.,Franceschini, S. C. C.,Sant'Ana, L. F. R.,Ribeiro, R. C. L. } \\
\text { (2011). Implementation and impact of the National Iron Supplementation Program in the city of Viçosa, } \\
\text { State of Minas Gerais Ciencia e Saude Coletiva, 16(10), } 4011-4022\end{array}$ & Language of publication \\
\hline 7 & $\begin{array}{l}\text { Friel, J. K. (2010). Some but not all breast-fed infants benefit from iron supplementation FASEB } \\
\text { journal, } 24\end{array}$ & Publication status \\
\hline 8 & $\begin{array}{l}\text { Gahagan, S.,Yu, S.,Kaciroti, N.,Castillo, M.,Lozoff, B. (2009). Linear and ponderal growth trajectories } \\
\text { in well-nourished, iron-sufficient infants are unimpaired by iron supplementation J Nutr, 139(11), 2106- } \\
12\end{array}$ & Intervention/exposure vs comparator \\
\hline
\end{tabular}


9 Gondolf, Ulla Holmboe,Tetens, Inge,Michaelsen, Kim F.,Trolle, Ellen (2013). Iron supplementation is positively associated with increased serum ferritin levels in 9-month-old Danish infants British Journal of Nutrition, 109(1), 103-110

10 Jabbari, Hossein,Bakhshian, Fariba,Asgari, Mohammad,Sattari, Mohammadreza,Naghavi-Behzad, Mohammad,Mashayekhi, Simin Ozar (2013). Antenatal Micronutrient Supplementation Relationship with Children's Weight and Height from Birth up to the Age of 18 Months Iranian Journal of Public Health, 42(6), 626-634

11 Lopez de Romana, G.,Cusirramos, S.,Lopez de Romana, D.,Gross, R. (2005). Efficacy of multiple micronutrient supplementation for improving anemia, micronutrient status, growth, and morbidity of Peruvian infants J Nutr, 135(3), 646s-652s

12 Medeiros, D. A.,Hadler, M. C.,Sugai, A., Torres, V. M. (2015). The effect of folic acid supplementation with ferrous sulfate on the linear and ponderal growth of children aged 6-24 months: a randomized controlled trial Eur J Clin Nutr, 69(2), 198-204

13 Pongcharoen, T.,Ramakrishnan, U.,DiGirolamo, A. M.,Winichagoon, P.,Flores, R.,Singkhornard, J.,Martorell, R. (2012). Influence of prenatal and postnatal growth on intellectual functioning in schoolaged children Arch Pediatr Adolesc Med, 166(5), 411-6

14 Ramakrishnan, U.,Neufeld, L. M.,Flores, R.,Rivera, J.,Martorell, R. (2009). Multiple micronutrient supplementation during early childhood increases child size at $2 \mathrm{y}$ of age only among high compliers Am J Clin Nutr, 89(4), 1125-31

15 Reid, B. M.,Doom, J. R.,Argote, R. B.,Correa-Burrows, P.,Lozoff, B.,Blanco, E.,Gahagan, S. (2019). Pathways to inflammation in adolescence through early adversity, childhood depressive symptoms, and body mass index: A prospective longitudinal study of Chilean infants Brain Behav Immun

16 Richard, S. A.,Zavaleta, N.,Caulfield, L. E.,Black, R. E.,Witzig, R. S.,Shankar, A. H. (2006). Zinc and iron supplementation and malaria, diarrhea, and respiratory infections in children in the Peruvian Amazon Am J Trop Med Hyg, 75(1), 126-32 
19 Sant'Ana, Lfdr,Cruz, Acrfd,Franceschini, Sdcc,Costa, N. M. B. (2006). Effect of a multi-mixture in the nutritional status of preschool children regarding iron Revista de nutricao, 19(4), 445-454

20 Wasantwisut, E.,Winichagoon, P.,Chitchumroonchokchai, C.,Yamborisut, U.,Boonpraderm, A.,Pongcharoen, T.,Sranacharoenpong, K.,Russameesopaphorn, W. (2006). Iron and zinc

Country supplementation improved iron and zinc status, but not physical growth, of apparently healthy, breastfed infants in rural communities of northeast Thailand J Nutr, 136(9), 2405-11

21 Yalcin, S. S.,Yurdakok, K.,Acikgoz, D.,Ozmert, E. (2000). Short-term developmental outcome of iron prophylaxis in infants Pediatr Int, 42(6), 625-30

Country

22 Yang, Q.,Yin, S.,Zhao, X.,An, J. (2004). Effect of daily or once weekly iron supplementation on growth and iron status of preschool children Wei sheng yan jiu [Journal of hygiene research], 33(2), 205-207

23 Yurdakok, K.,Temiz, F.,Yalcin, S. S.,Gumruk, F. (2004). Efficacy of daily and weekly iron supplementation on iron status in exclusively breast-fed infants J Pediatr Hematol Oncol, 26(5), 284-8

Language of publication

\section{Country}

